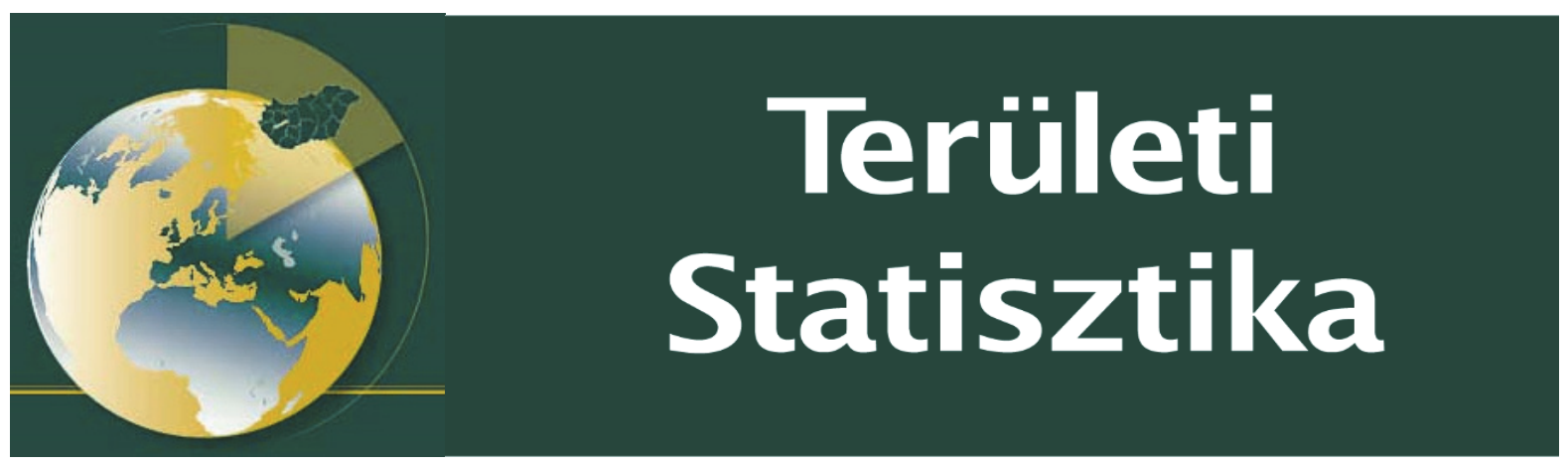

Közzététel: 2019. július 25.

A tanulmány címe:

Szerzők:

A gazdasági és az energetikai erőterek elmozdulása a világon

Sebestyénné Szép Tekla Miskolci Egyetem, Gazdaságtudományi Kar, Világ- és Regionális

Gazdaságtan Intézet E-mail: regtekla@uni-miskolc.hu

Tóth Géza Központi Statisztikai Hivatal, Miskolci Egyetem, Gazdaságtudományi Kar,

Világ- és Regionális Gazdaságtan Intézet E-mail: Geza.Toth@ksh.hu

https://doi.org/10.15196/TS590401

Az alábbi feltételek érvényesek minden, a Központi Statisztikai Hivatal (a továbbiakban: KSH)

Területi Statisztika c. folyóiratában (a továbbiakban: Folyóitat) megjelenó tanulmányra. Felhasználó a tanulmány, vagy annak részei felhasználásával egyidejüleg tudomásul veszi a jelen dokumentumban foglalt felhasználási feltételeket, és azokat magára nézve kötelezốnek fogadja el. Tudomásul veszi, hogy a jelen feltételek megszegéséból eredố valamennyi kárért feleloósséggel tartozik.

1) A jogszabályi tartalom kivételével a tanulmányok a szerzői jogról szóló 1999. évi LXXVI. törvény (Szjt.) szerint szerzői műnek minősülnek. A szerzői jog jogosultja a KSH.

2) A KSH földrajzi és időbeli korlátozás nélküli, nem kizárólagos, nem átadható, térítésmentes felhasználási jogot biztosít a Felhasználó részére a tanulmány vonatkozásában.

3) A felhasználási jog keretében a Felhasználó jogosult a tanulmány:

a) oktatási és kutatási célú felhasználására (nyilvánosságra hozatalára és továbbítására a

4. pontban foglalt kivétellel) a Folyóirat és a szerző(k) feltüntetésével;

b) tartalmáról összefoglaló készítésére az írott és az elektronikus médiában a Folyóirat

és a szerző(k) feltüntetésével;

c) részletének idézésére - az átvevő mú jellege és célja által indokolt terjedelemben és az eredetihez híven - a forrás, valamint az ott megjelölt szerző(k) megnevezésével.

4) A Felhasználó nem jogosult a tanulmány továbbértékesítésére, haszonszerzési célú felhasználására. Ez a korlátozás nem érinti a tanulmány felhasználásával előállított, de az Szjt. szerint önálló szerzői műnek minősülő mú ilyen célú felhasználását.

5) A tanulmány átdolgozása, újra publikálása tilos.

6) A 3. a)-c.) pontban foglaltak alapján a Folyóiratot és a szerző(ke)t az alábbiak szerint kell feltüntetni:

„Forrás: Területi Statisztika c. folyóriat 59. évfolyam 4. számában megjelent, Sebestyénné Szép Tekla - Tóth Géza által irt, A gazdasági és az energetikai eróterek elmozdulása a világon c. tanulmány"

7) A Folyóiratban megjelenő tanulmányok kutatói véleményeket tükröznek, amelyek nem esnek szükségképpen egybe a KSH, vagy a szerzők által képviselt intézmények hivatalos álláspontjával. 


\section{A gazdasági és az energetikai eröterek elmozdulása a világon}

\section{Movements of economic and energy field forces in the world}

Sebestyénné Szép Tekla

Miskolci Egyetem, Gazdaságtudományi Kar,

Világ- és Regionális

Gazdaságtan Intézet

E-mail:

regtekla@uni-miskolc.hu

Tóth Géza

Központi Statisztikai Hivatal,

Miskolci Egyetem, Gazdaságtudományi Kar,

Világ- és Regionális

Gazdaságtan Intézet

E-mail:Geza.Toth@ksh.hu

Kulcsszavak: gravitációs erôtér, energiafelhasználás, gazdasági növekedés, gazdasági szerkezet változása, súlypont
A statisztikai adatok egyértelmúen azt mutatják, hogy az energiakereslet változásai és tendenciái nagyon hasonlóak a világgazdaságban végbemenő átrendeződésekhez, jelezve a két folyamat közötti kapcsolat szorosságát. Fokozódó energiafelhasználás, illetve gazdasági teljesítmény figyelhető meg a feltörekvő országokban, ezzel párhuzamosan részesedésük a világ energiafelhasználásából és bruttó hazai termékéből folyamatosan növekszik, ami jelentős (térbeli) elmozdulásokhoz vezet. A tanulmány gravitációsmodellszámítással vizsgálja a világ energetikai és gazdasági erőterének 1990 és 2015 közötti változását. A módszer segítségével a szerzők bemutatják az egyes kontinenseken, illetve országcsoportokban zajló - időnként ellentétes irányú - fô folyamatokat, rávilágítanak a fennálló különbségekre. Az alkalmazott kétdimenziós regressziószámítás mélyebb elemzést tesz lehetôvé, a gravitációsmodell-számítás eredményeként kapott ponthalmazokat (a GDP és a végső energiafelhasználás vonatkozásában) a szerzők összevetik, az eredményekből következtetéseket vonnak le arról, hogyan változik, illetve torzul a tér a gravitációs erőtér következtében. Az újszerû megközelítésű tanulmány további adalékkal szolgál a két mutató közötti kapcsolat komplex vizsgálatához. 
Based on statistical data it can be clearly stated that the changes and trends in energy demand are very similar to the rearrangements in the world economy, indicating the tightness of the relationship between the two processes. Increasing energy consumption and economic performance are observed in emerging countries, while their share of the world's energy consumption and global GDP is growing steadily, resulting in significant (spatial) shifts. The study examines the evolution of the world's energy and economic power from 1990 to 2015 by gravity modelling. Using this method, the authors present the main processes occurring in each continent or group of countries - sometimes in the opposite direction - and highlight the differences that exist. The applied bi-dimensional regression calculation allows for a deeper analysis, the authors compare the set of points resulting from the gravitational computation (for GDP and

Keywords: final energy consumption) and draw conclusions gravity field, from the results about how the space changes and energy consumption, becomes distorted due to the gravity field. This economic growth, novel approach is another addition to the comchanging economic structure, weighted mean centre plex question of the relationship between the two indicators.

Beküldve: 2018. május 31.

Elfogadva: 2018. június 22.

\section{Bevezetés}

Az egyes országok (illetve a világ) energiafelhasználását tényezők sokasága befolyásolja: többek között a gazdasági növekedés, a népesség számának változása, az urbanizációs folyamatok, a gazdasági szerkezet változása (a primer, szekunder és tercier szektor arányának módosulása), az egyes iparágak energiaintenzitása, az energiahatékonyság, az egyes energiaforrások szerepe az energiamixben, illetve - nem utolsósorban - a nemzeti energiapolitika. 
Tanulmányunkban az UN (2017) és az IMF (2017) országbesorolásának figyelembevételével a következő országcsoportokat alakítottuk ki:

- fejlett országok, mely az IMF (2017) szerinti advanced economies kategóriába tarozó országokat tartalmazza, illetve az egyéb OECD-országokat és az egyéb EU-tagállamokat;

- átmeneti gazdaságok az IMF (2017) szerinti economies in transition kategóriába tartozó országokat tömöríti: Dél-Kelet-Európa átmeneti gazdaságait és a Független Államok Közösségét (FÁK-országok), valamint Grúziát (megjegyezzük, hogy jelentôs átfedés van az átmeneti gazdaságok és az üzemanyagexportáló országok között; amennyiben egy ország szerepel az utóbbiban, az előbbiben már nem);

- üzemanyag-exportáló országok az IMF (2017) szerinti fuel-exporting countries kategóriába tartozó országok;

- fejlődő országok: minden egyéb ország Ázsiában, Latin-Amerikában, valamint Afrikában.

A fejlett és a fejlődő (illetve átmeneti gazdaságok) országok között jelentős az eltérés a gazdaság energiaintenzitásában. Az 1. ábra szerint, míg 1990-ben a fejlett országok termelték meg a világ bruttó hazai termékének (gross domestic product GDP) több mint négyötödét, addig ez az arány 2015-re 65\% alá esett vissza. Ugyanakkor a világ végső energiafelhasználásából mindig is kisebb mértékben részesedtek ezen országok (összehasonlítva a világ többi részével): 1990-ben a fogyasztás körülbelül felét, 2015-ben valamivel több mint 40\%-át tették ki. Először 2008-ban haladta meg a Gazdasági Együttmúködési és Fejlesztési Szervezethez tartozó (Organisation for Economic Co-operation and Development - OECD-) országokét a nem OECD-országok energiafelhasználása. Ezen arányokból következtetések adódnak az energiaintenzitásra: a fejlett országok gazdaságának jóval hatékonyabb az energiafelhasználása, ami elsősorban a szolgáltató szektor, valamint az alkalmazott technológia fejlettségével, továbbá a környezet- és energiapolitikával magyarázható.

Az arányok átrendeződése még nem tekinthető végleges és lezárt folyamatnak. A World Energy Council (2017a, b) előrejelzése szerint a világ primer energiaigénye 2014 és 2060 között lassuló ütemben, de tovább fog nőni (2014 és 2030 között várhatóan 1,4-1,7\% lesz az éves növekedési ráta, míg 2030 és 2060 között 0,5-1,0\%). Ugyanakkor az energia, különösen az olaj és egyéb fosszilis energiahordozók iránti keresletnövekedés jelentős hányada már nem a fejlett, iparosodott országokban jelentkezik, hanem a feltörekvő gazdaságokban, így - többek között - Kínában és Indiában. Ezen országok modernizálódása, iparosodása, illetve urbanizálódása erōteljesen hozzájárul energiaéhségük növekedéséhez (Zhang et al. 2011). Ez a tendencia felhívja a figyelmet a gazdasági és az energetikai súlypontok eltolódására.

Területi Statisztika, 2019, 59(4): 353-380; DOI: 10.15196/TS590401 
A világ GDP-jének és végső energiafelhasználásának* megoszlása

1. ábra az egyes országcsoportok között

Distribution of world GDP and final energy consumption by country group $\%$

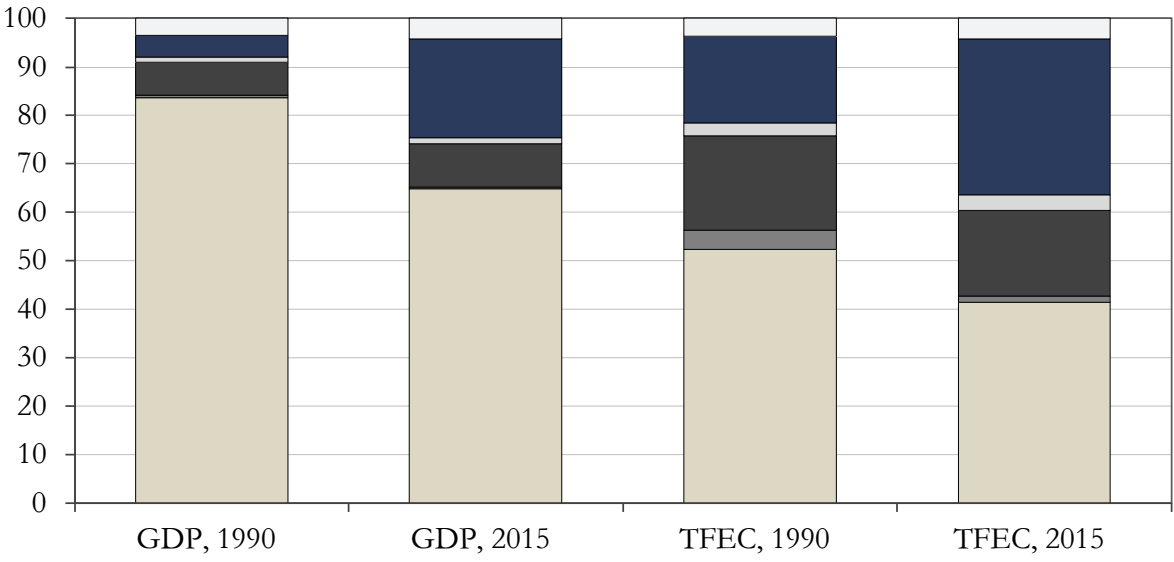

$\square$ Fejlődô országok - Latin-Amerika és a Karib-térség

- Fejlődő országok - Ázsia

$\square$ Fejlődő országok - Afrika

—Üzemanyag-exportáló országok

$\square$ Átmeneti gazdaságok

$\square$ Fejlett országok, egyéb OECD-országok, egyéb EU-tagállamok

* Végső energiafelhasználás (total final energy consumption - TFEC).

Forrás: saját szerkesztés a Világbank (2018a, b) alapján.

A továbbiakban - az 1. táblázat adatai alapján - ötéves periódusokban vizsgáljuk az energiafogyasztás és a gazdasági növekedés alakulását. Míg a fejlett országokban enyhén növekedett az energiafelhasználás 1990 és 2000 között (1990 és 1995 között 0,9 és 1995 és 2000 között 1,7\%-kal), ezt követően azonban a növekedés megáll, sőt 2005 után csökkenésre váltott. Az okok elsősorban a 2008-2009-es gazdasági világválsággal, a fenntarthatóságra fókuszáló gazdasági fejlődéssel, a strukturális átalakulással (az energiaintenzív iparágak kihelyezése a fejlődő országokba), illetve egyéb energiahatékonysági intézkedésekkel (ezen országok aktív támogatói a klímavédelmi célok elérésének) függnek össze. A fejlődő és az üzemanyag-exportáló országokban ugyanakkor az energiafogyasztás intenzíven növekedett 2010-ig. A súlypont az északi féltekérôl áthelyeződött a délire, ami elsősorban az ezredforduló utáni gazdasági konjunktúra és növekedési boom eredménye. Az ezt követô években azonban lassabban növekedett az energiafelhasználás, melynek okai - részben - Kínában keresendők. Kína évek óta a gazdasági túlhevülés jeleit mutatta, a növekvő egyensúlyta-

Területi Statisztika, 2019, 59(4): 353-380; DOI: 10.15196/TS590401 
lanságokat (például jüan/USD-árfolyam, az Egyesült Államokkal fennálló hatalmas kereskedelmi többlet, bővülő fogyasztás, csökkenő megtakarítás, magas beruházási ráta, valamint az árnyékbankrendszer veszélyei) kiegyenlítő gazdasági mechanizmusok nem tudtak megfelelően érvényesülni. 2010 óta a kínai gazdasági növekedési ráta csökkenő tendenciájú, ami egybevág a kínai vezetés gazdaságlehútési céljaival (Szabó 2010). Ez nyilván az energiafelhasználásban is tetten érhető, és mivel Kína felelős a világ energiafelhasználásának több mint egyötödéért (2017-ben már a világ legnagyobb olajimportőrévé vált), így meghatározó szerepe van nemcsak a fejlődő országok energiafelhasználásában, hanem az energiaárak alakításában is. Az egykori Szovjetunió érdekszférájába tartozó, ún. átmeneti országokban a rendszerváltás, illetve a nehézipar leépülésével bekövetkezett radikális szerkezetváltással 2000-ig csökkent az energiafelhasználás, majd egy átmeneti időszaktól eltekintve azóta se indult növekedésnek.

1. táblázat

\section{A GDP és a végső energiafelhasználás éves átlagos változása} a különböző országcsoportokban

Annual average change in GDP (current prices, USD) and final energy consumption (TJ) in different country groups, percent

\begin{tabular}{|c|c|c|c|c|c|c|c|c|c|c|}
\hline \multirow{2}{*}{ Országcsoportok } & \multicolumn{2}{|c|}{$1995 / 1990$} & \multicolumn{2}{|c|}{$2000 / 1995$} & \multicolumn{2}{|c|}{$2005 / 2000$} & \multicolumn{2}{|c|}{$2010 / 2005$} & \multicolumn{2}{|c|}{$2015 / 2010$} \\
\hline & GDP & TFEC & GDP & TFEC & GDP & TFEC & GDP & TFEC & GDP & TFEC \\
\hline $\begin{array}{l}\text { Fejlett országok, egyéb } \\
\text { OECD-országok, } \\
\text { egyéb EU-tagállamok }\end{array}$ & 6,5 & 0,9 & 1,5 & 1,7 & 6,5 & 0,6 & 3,9 & $-0,2$ & 1,0 & $-0,3$ \\
\hline Átmeneti gazdaságok & $-4,4$ & $-10,5$ & $-4,6$ & $-3,1$ & 21,0 & 1,7 & 12,4 & $-0,4$ & $-1,6$ & $-3,4$ \\
\hline $\begin{array}{l}\text { Üzemanyag-exportáló } \\
\text { országok }\end{array}$ & $-0,8$ & $-2,0$ & 2,3 & 0,5 & 14,5 & 2,3 & 17,0 & 3,2 & 1,6 & 1,6 \\
\hline $\begin{array}{l}\text { Fejlődő országok } \\
\text { ebből: }\end{array}$ & 10,4 & 3,4 & 3,3 & 1,1 & 9,8 & 5,7 & 17,9 & 5,0 & 7,8 & 3,3 \\
\hline Afrika & 10,8 & 3,7 & 6,8 & 0,6 & 12,0 & 6,7 & 18,9 & 5,5 & 10,6 & 3,5 \\
\hline Ázsia & 4,2 & 2,0 & $-0,1$ & 2,1 & 12,3 & 3,3 & 10,0 & 2,4 & 1,6 & 2,8 \\
\hline $\begin{array}{l}\text { Latin-Amerika és a } \\
\text { Karib-térség }\end{array}$ & 12,7 & 2,7 & $-0,5$ & 3,3 & 5,1 & 2,0 & 18,0 & 3,6 & 0,2 & 2,0 \\
\hline Világ & 6,3 & 0,6 & 1,7 & 1,3 & 7,3 & 2,4 & 7,0 & 2,1 & 2,5 & 1,3 \\
\hline
\end{tabular}

Megjegyzés: a számításokhoz felhasznált adatok mértékegysége a GDP esetében folyó áras USD, a végső energiafelhasználás esetében TJ.

Forrás: saját számítás a Világbank (2018a, b) alapján.

$\mathrm{Az}$ ismertetett folyamatok vizualizációja, térképi megjelenítése hiányosnak tekinthető, ugyanis a szakirodalomban mindössze néhány tanulmány vizsgálja és ábrázolja az energetikai erőtereket (például Zhang et al. 2012, Wang et al. 2014).

Területi Statisztika, 2019, 59(4): 353-380; DOI: 10.15196/TS590401 
Az energiafelhasználás és a gazdasági növekedés földrajzi különbségeinek feltárása, a térbeli folyamatok megértése számos, globálisan jelentkező probléma vizsgálatához alapvető fontosságú. Információt nyújt az energiabiztonság, a globális környezeti kihívások témaköréhez, illetve hozzájárulhat további energetikai vizsgálatokhoz. A területi elemzések eszközként szolgálnak a gazdasági és az energetikai erőterek elmozdulásának feltárásához, valamint vizualizációjához.

A továbbiakban elemzésünk fö célja, hogy a világ (mint egységes egész), illetve az egyes kontinensek energetikai és gazdasági gravitációs erőtereinek azonosítása, az elmozdulások (különös tekintettel azok irányára) feltárása. Az elméleti háttér fejezetben bemutatjuk a gravitációsmodell-, illetve súlypontszámítást alkalmazó tanulmányok eredményeit, továbbá összegezzük az energiafelhasználás és a gazdasági növekedés kapcsolatrendszerét jellemző fontosabb álláspontokat. A módszertan és felhasznált adatok fejezet ismerteti a felhasznált adatbázisokat, továbbá a súlypontszámítás és a kétdimenziós regressziószámítás módszertani kérdéseit. Az eredmények fejezetben térképek segítségével bemutatjuk a gazdasági és az energetikai erôtér elmozdulási irányait globálisan, illetve kontinensenként, továbbá a kétdimenziós regressziószámítás eredményei alapján következtetéseket vonunk le. A tanulmány végén összegezzük megállapításainkat.

\section{Elméleti háttér}

\section{Energiafelhasználás és gazdasági növekedés}

Az energia gazdaságban betöltött szerepével kapcsolatos vélemények igen széles skálán mozognak. Mind az ökológiai, mind az energia-gazdaságtan képviselői a gazdasági növekedés fó mozgatórugójának az energiát, illetve az energiafelhasználást tartják, sôt egyes radikális nézőpontok szerint az energiafelhasználás a gazdasági fejlettség kizárólagos mérőszáma (például Duncan [2006] Olduvai-elmélete). Elméletüket az energiának a termelésben betöltött fontos szerepével magyarázzák, azzal érvelnek, hogy nincs olyan gazdasági tevékenység, melyhez ne lenne szükség energiára (Stern-Cleveland 2004, Stern 2011), abból az egyszerú tényből kiindulva, hogy a termelés egy munkafolyamat, és a munkavégzés energiabefektetéssel jár (Murphy 2011). Számos tanulmány hangsúlyozza az energiafelhasználás és a gazdasági növekedés közötti kapcsolat szorosságát, sőt megállapítja, hogy „egy adott ország gazdasági-jóléti színvonalát az energiafelhasználás mértéke is jellemzi” (Kovács 2007a, 63. old.), illetve „az ásványi nyersanyagtermelés, az energiaigények biztosítása a gazdaság és az életszínvonal emelésének egyik alapvető pillére" (Kovács 2007b, 47. old.). Hasonló álláspontot képviselnek Lakatos-Lakatosné Szabó (2008), a globális GDP és a kőolajszükséglet közötti kapcsolatot fejtegetve.

Megállapítható, hogy az ökológiai és az energia-gazdaságtan képviselői egyetértenek az energia gazdasági növekedésben betöltött elsődleges szerepével. Abban

Területi Statisztika, 2019, 59(4): 353-380; DOI: 10.15196/TS590401 
azonban már jelentős különbségek mutatkoznak, hogy hogyan képzelik el ezt a szerepet. Cleveland (2003) az energia elérhetőségét hangsúlyozza, Murphy (2011) szerint a felhasznált energia mennyiségének növekedése a fontos. Berndt-Wood (1975), illetve Schurr (1982) az elsők között ismerik fel az energia minőségének gazdasági fontosságát: véleményük szerint a villamos energia a jelenleg elérhető legjobb minőségű energiaforrás, továbbá - elsősorban - az energia minőségének javulása járult hozzá a fejlett országok energiaintenzitásának fejlődéséhez. Stern (2009) szintén az energia minőségének gazdaságban betöltött fontossága mellett érvel. Ayres és szerzőtársai (2003), Ayres-Warr (2005) az energia árának csökkenésével magyarázzák az első és a második ipari forradalom hatására bekövetkező gazdasági fejlődést, továbbá azzal, hogy az energia (illetve az általa elérhető munkavégző képesség növekedése) szélesebb néprétegek számára elérhetôvé vált (például belső égésű motorok). Akizu (2017) is azt emeli ki, hogy emberiség történetében elsősorban az első, a második és a harmadik ipari forradalom eredményezett ugrásszerú fejlődést, ugyanakkor az újonnan felfedezett technológiai vívmányok jelentős része valamilyen - addig nem ismert, vagy nem kelló hatékonysággal felhasznált - energiaforráshoz kötődött (szén - gőzgépek; kőolaj - belső égésű motorok; nukleáris energia - olcsó villamos energia). Nemcsak az energiafelhasználás és a gazdasági növekedés, hanem az energiafelhasználás és az emberi fejlettség indexe (human development index - HDI) között is pozitív irányú, szoros kapcsolat figyelhető meg (Arto 2016). A szétválás (decoupling) elméletének is ez az alapvető feltételezése, nevezetesen, hogy ezen indikátorok között intenzív ok-okozati kapcsolat van. Célja a környezeti terhelés és a gazdasági növekedés szétválasztása, melyre a fenntartható fejlődés megvalósításának egyik lehetséges eszközeként tekint.

Az energia-gazdaságtan (energy economics), az energiaföldrajz (energy geographics; a tudományterület részletes leírását adja Munkácsy (2018) és Calvert (2016)), valamint az energia-geopolitika (energy geopolitics) határterületeként értelmezhető a globális energiafelhasználás térbeli folyamatainak, illetve a fogyasztás hatóerőinek vizsgálata, továbbá a globális energiapiacok átrendeződése (összhangban a világgazdaság fejlôdésével, a feltörekvő országok növekvő részesedésével). Jelen tanulmányunkat az energia-gazdaságtanhoz tartjuk közelebb állónak, hiszen központi kérdésünk az, hogy a gazdasági növekedés és az energiafelhasználás milyen kapcsolatban van egymással, miként hatnak egymásra időben és térben. A két tényező közötti korreláció, illetve az oksági kapcsolat vizsgálata fontos része az energia-gazdaságtani kutatásoknak. A témában úttörő munkának számít Kraft-Kraft (1978) publikációja, ami az energiafogyasztás és a bruttó nemzeti termék (gross national product - GNP) közötti oksági kapcsolatot vizsgálja az Egyesült Államokban, az 1947 és 1974 közötti idôszakban. Az azóta eltelt évtizedekben számos további publikáció született, ugyanakkor - itt jegyezzük meg - a kutatási eredmények mind a mai napig nem egységesek.

Területi Statisztika, 2019, 59(4): 353-380; DOI: 10.15196/TS590401 
Tanulmányunk kiindulópontja az a feltételezés, miszerint a világgazdasági folyamatokban pozitív irányú, szoros kapcsolat figyelhető meg az energiafelhasználás és a gazdasági növekedés között. Ez alapján célszerünek látjuk a két indikátor térbeli együttmozgásának vizsgálatát. Hipotéziseink a következők:

1. Nemcsak globálisan, hanem az egyes kontinensek esetében is az energetikai és a gazdasági erôterek mozgása szorosan követi egymást.

2. Az erőterek modellezéséhez használt súlypontok vizsgálatából következtetni lehet a két mutató közötti ok-okozati kapcsolatra.

\section{Erőterek a világban, avagy a gravitációsmodell-számítás}

A gravitációs analógián alapuló módszerek alkalmazása nem új keletủ a szakirodalomban, ezeket részletesen áttekinti Nagy (2011). Kincses-Tóth (2012) alapján kijelenthetô, hogy a fizikai analógián alapuló gravitációsmodell-számításokat elsősorban a térbeli áramlások vizsgálatához, valamint a vonzáskörzetek lehatárolásához alkalmazzák (Guzik et al. 2017). A térszerkezet elemzéséhez léteznek más gravitációs analógián alapuló modellek is (Csomós-Tóth 2016).

Quah (2011) mérföldkőnek számító munkájában - mely nagymértékben épít Klein (2009), valamint Grether-Mathys (2010) tapasztalataira - a globális gazdasági erőtér elmozdulását vizsgálja 1980 és 2007 között, 693 adatpontra végezve el a számításokat. Eredményei jelen tanulmányhoz hasonló irányú elmozdulást jeleznek, bár számításai alapján a gravitációs erôteret jellemző súlypontok nem a Földközi-tenger medencéjében, hanem attól délebbre, Afrika északi partvonalán helyezkednek el. Ugyanakkor vizsgálatunk túlmutat Quah (2011) kutatási célkitűzésein. Fő célunk nem a gazdasági erőtér meghatározása, illetve az elmozdulások nyomon követése, hanem ezen térbeli változások összevetése az energetikai erôtér esetében tapasztalt mozgásokkal. Ezáltal az együttmozgások (avagy széttartások, divergenciafolyamatok) azonosíthatóvá válnak, mely adalékkal szolgál az energiafelhasználás és a gazdasági növekedés közötti kapcsolatrendszer vizsgálatához, térbeliségének elemzéséhez.

Szakirodalmi kutatásunk alapján megállapítható, hogy az energetikai erőterek mint kutatási téma meglehetősen alulprezentált, mindössze néhány tanulmány (így Fesharaki 1996, Zhang et al. 2012, Wang et al. 2014) fókuszál erre a kérdéskörre. Fesharaki (1996) tanulmánya az elsők között használta az energetikai erőterek kifejezést. Vizsgálata során Ázsia, illetve a csendes-óceáni térség felértékelődése mellett érvelt, bár következtetéseit csak a statisztikai adatok változásának elemzéséből vonta le, gravitációsmodell-számítást nem végzett.

A kínai energiafelhasználás keresleti és kínálati oldalát Zhang és szerzőtársai (2012) már gravitációsmodell-számítással vizsgálták az 1997 és 2009 időszakra, energiaforrások (szén, kőolaj, földgáz és villamos energia) szerint. Kutatásukkal felhívták a figyelmet az energiatermelés és -felhasználás térbeli különbségeire, javaslatokat fogalmazva meg az infrastruktúra fejlesztésére.

Területi Statisztika, 2019, 59(4): 353-380; DOI: 10.15196/TS590401 
Wang és szerzőtársai (2014) a világ energiafelhasználásának és energiatermelésének gravitációs erőtereit vizsgálták a kőolaj, a földgáz és a kőszén esetében. Az erőterek dél-délkeleti irányú elmozdulásán túlmenően számszerűsítették annak sebességét is, bár az okozatok feltárása hiányzik a tanulmányból.

\section{Módszertan és felhasznált adatok}

Számításainkhoz a Világbank (2018a, b) adatbázisait használtuk fel 204 adatpont (ország, területi egység, illetve tartomány) vonatkozásában. A folyó áron, USD-ben számított GDP és a végső energiafelhasználás (TJ) adatait az 1990 és 2015 közötti időszakban vizsgáltuk.

\section{A gravitációs modell, különös tekintettel a súlypontmódszerre}

Nemes Nagy (1998) alapján a súlypontszámítás a következők szerint történik. „Egy n pontból álló síkbeli pontrendszer súlypontjának koordinátái, ha a pontok helyzete a koordináta-rendszerben (térképen) adott, és minden ponthoz egy-egy „súly” (tömeg) tartozik, a pontok koordinátáinak súlyozott számtani átlagaként számíthatók":

$$
x=\frac{\sum_{i=1}^{n} f_{i} x_{i}}{\sum_{i=1}^{n} f_{i}}, y=\frac{\sum_{i=1}^{n} f_{i} y_{i}}{\sum_{i=1}^{n} f_{i}}
$$

ahol $x$ és $y$ a súlypont két (földrajzi) koordinátája; $x_{i}$ és $y_{i}$ az alappontok (földrajzi) koordinátáit, $f_{i}$ pedig az alappontokhoz tartozó súlyokat jelöli. Ha a súlyok azonosak, akkor a pontrendszer geometriai súlypontját adja meg a számítás. Az eredményként kapott helykoordináták jelzik a végleges súlypontot (Nemes Nagy 1998, 190. old.).

A súlypontszámítás történhet bármilyen területi egységre, találunk példát globális számításokra is (például Grether-Mathys 2010, Quah 2011), illetve egy-egy régiót középpontba állító vizsgálatok is fellelhetők (például Zhang et al. 2012). Ahogy azt Nemes Nagy (1998) megerősíti, a számítás során használt súly lehet bármilyen gazdasági vagy társadalmi tartalmú „tömegmérték” is, így akár népesség, jövedelem, a foglalkoztatottak száma, energiafelhasználás, emisszió. Amennyiben az egyes súlypontok elmozdulásait vizsgáljuk, azzal képet kaphatunk a térbeli folyamatokról, azok irányáról, erősségéról. Hátránya a módszernek, hogy amennyiben a térszerkezeti változások a súlypont körül egyenletesen, azaz szimmetrikusan zajlanak, akkor hiába vannak jelentős változások, azt a súlypont nem követi (Nemes Nagy 1998). Megjegyezzük, hogy jelen tanulmányunkban globális folyamatokat vizsgálunk. A világgazdasági rendszerek komplexitása, a világ országainak sokszínúsége kizárja azt a lehetőséget, hogy az energiafelhasználás és a gazdasági növekedés térbeli folyamatai szimmetrikusak legyenek egy-egy súlypont esetében, mely csökkenti e probléma jelentőségét.

Korábbi (Tóth-Nagy 2016) tanulmányunkhoz hasonlóan a vizsgált országok mértani középpontját súlyozzuk a nominális GDP, valamint a végső energiafelhasz-

Területi Statisztika, 2019, 59(4): 353-380; DOI: 10.15196/TS590401 
nálás értékeivel. Ez a módszer - különösen a földrajzilag nagy kiterjedésú országok esetében - számos problémát vet fel, hiszen sok esetben a mértani közép távol esik bármilyen jelentős várostól, ipari központtól. Azonban - jelen tanulmány céljai szempontjából - nem a súlypontok konkrét térbeli elhelyezkedése a fontos (még ha az elemzésben meg is említjük), hanem az időbeli változások, illetve a két pontállomány együttmozgása. Éppen ezért annak ellenére, hogy létezik a szakirodalomban olyan módszer, mely kiküszöböli a projekció hatását (Jenness 2004, Durocher et al. 2017), magunk részéről annak alkalmazásától eltekintettünk, úgy véltük a súlypontszámítás eredeti módszere célunknak megfelelő. A súlypontok konkrét elhelyezkedését természetesen azért sem tekintettük mérvadónak, mert a gazdasági tevékenység, illetve az energiahasználat sok esetben az országok csupán egy részére szorítkozik (lásd Kína), míg mi az államterület mértani központját súlyoztuk kutatásunk során. Tehát a konkrét elhelyezkedésnél sokkal fontosabb a tendenciák és a térbeli együttmozgások vizsgálata. Az eredményekből megfelelő következtetések vonhatóak le a világgazdaságban végbemenő folyamatok, változások (például a 4 jelentős feltörekvő gazdaság (Brazília, Oroszország, India, Kína, azaz a BRIC-országok felemelkedése és ezzel párhuzamosan növekvő energiafelhasználása, valamint az Egyesült Államok, az Európai Unió és Japán gazdasági háromszöge (Triád) relatív gazdasági súlyának csökkenése) irányára vonatkozóan. A módszer alkalmazásával nyert információk további adalékkal szolgálnak a globális folyamatok és átrendeződések megértéséhez. A pontok elhelyezkedésének megállapításához, illetve a térképek elkészítéséhez az Eurostat jelenlegi európai szabványrendszerét, vetületi rendszerét (European Terrestrial Reference System - ETRS89) használjuk fel.

Elemzésünk során nem csupán a világot vizsgáljuk meg, hanem az egyes kontinenseket külön-külön is: Afrika, Ázsia, Európa (Oroszországgal együtt), Amerika (Észak-Amerika és Latin-Amerika) és Ausztrália (Óceániával együtt).

\section{Kétdimenziós regresszió alkalmazása}

A gravitációsmodell-számítás eredményeként kapott ponthalmazok (a GDP és a végső energiafelhasználás vonatkozásában) célszerű összevetése megmutatja, hogyan változik, torzul a tér az erôtér következtében. Ez természetesen történhet pusztán térképi ábrázolással, de az ilyen nagyszámú pont mellett nem kecsegtethet igazán jó eredménnyel. Sokkal kedvezőbb a kétdimenziós regresszió alkalmazása, mely a térbeli alakzatok összehasonlításának egyik módszere. Az összehasonlítást úgy teszi lehetővé, hogy az egymástól eltérő koordináta-rendszerben lévő pontalakzatok közül az egyiket a másik koordináta-rendszerébe transzformálja, a megfelelő mértékű eltolással, elforgatással és átskálázással. Az ily módon közös koordináta-rendszerbe transzformált alakzatok pontjai közötti egyedi és összesített különbségek alapján meghatározható az alakzatok lokális és globális hasonlóságának, illetve különbözőségének mértéke. A módszer kidolgozása Tobler (1961, 1965, 1970, 1978, 1994, 2004) nevéhez füződik, aki az 1960-as és 1970-es évekbeli előzményeket követően

Területi Statisztika, 2019, 59(4): 353-380; DOI: 10.15196/TS590401 
1994-ben publikálta az eljárást ismertető tanulmányát. Az euklidészi változat számításával kapcsolatos egyenletekhez lásd Tobler (1994), Friedman-Kohler (2003), Dusek (2011, 2012) munkáit.

2. táblázat

A kétdimenziós euklidészi regresszió egyenletei

Equations of bi-dimensional Euclidean regression

\begin{tabular}{|c|c|}
\hline Megnevezés & Egyenlet \\
\hline $\begin{array}{l}\text { 1. A regresszió } \\
\text { egyenlete } \\
\text { 2. Skálakülönbség }\end{array}$ & 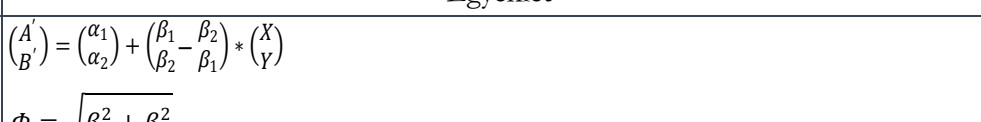 \\
\hline 3. Elforgatás & $\Theta=\tan ^{-1}\left(\frac{\beta_{2}}{\beta_{1}}\right)$ \\
\hline 4. $\beta_{1}$ kiszámítása & $\beta_{1}=\frac{\sum\left(a_{i}-\bar{a}\right) *\left(x_{i}-\bar{x}\right)+\sum\left(b_{i}-\bar{b}\right) *\left(y_{i}-\bar{y}\right)}{\sum\left(x_{i}-\bar{x}\right)^{2}+\sum\left(y_{i}-\bar{y}\right)^{2}}$ \\
\hline 5. $\beta_{2}$ kiszámítása & $\beta_{2}=\frac{\sum\left(b_{i}-\bar{b}\right) *\left(x_{i}-\bar{x}\right)-\sum\left(a_{i}-\bar{a}\right) *\left(y_{i}-\bar{y}\right)}{\sum\left(x_{i}-\bar{x}\right)^{2}+\sum(y-\bar{y})^{2}}$ \\
\hline 6. Vízszintes eltolás & $\alpha_{1}=\bar{a}-\beta_{1} * \bar{x}+\beta_{2} * \bar{y}$ \\
\hline 7. Függőleges eltolás & $\alpha_{2}=\bar{b}-\beta_{2} * \bar{x}-\beta_{1} * \bar{y}$ \\
\hline $\begin{array}{l}\text { 8. Korreláció a hiba- } \\
\text { tagok alapján }\end{array}$ & $r=\sqrt{1-\frac{\sum\left[\left(a_{i}-a_{i}^{\prime}\right)^{2}+\left(b_{i}-b_{i}^{\prime}\right)^{2}\right]}{\sum\left[\left(a_{i}-\bar{a}\right)^{2}+\left(b_{i}-\bar{b}\right)^{2}\right]}}$ \\
\hline $\begin{array}{l}\text { 9. Eltérésnégyzet- } \\
\text { összeg felbontása }\end{array}$ & $\begin{array}{l}\sum_{\mathrm{SST}=\mathrm{SSR}+\mathrm{SSE}}\left[\left(a_{i}-\bar{a}\right)^{2}+\left(b_{i}-\bar{b}\right)^{2}\right]=\sum\left[\left(a_{i}^{\prime}-\bar{a}\right)^{2}+\left(b_{i}^{\prime}-\bar{b}\right)^{2}\right]+\sum\left[\left(a_{i}-a_{i}^{\prime}\right)^{2}+\left(b_{i}-b_{i}^{\prime}\right)^{2}\right] \\
\end{array}$ \\
\hline 10. A' kiszámítása & $A^{\prime}=\alpha_{1}+\beta_{1}(X)-\beta_{2}(Y)$ \\
\hline 11. B’ kiszámítása & $B^{\prime}=\alpha_{2}+\beta_{2}(X)+\beta_{1}(Y)$ \\
\hline
\end{tabular}

Forrás: Tobler (1994) és Friedman-Kohler (2003) idézi Dusek (2011, 14. old.).

Ahol az x és y a független alakzat koordinátái; $a$ és $b$ a függő alakzat koordinátái; a' és b' a függő alakzat koordinátái a független alakzat rendszerében. $a_{1}$ a vízszintes eltolás mértékét határozza meg, míg $a_{2}$ a függőleges eltolás mértékét. $\beta_{1}$ és $\beta_{2}$ a skálakülönbség $(\Phi)$ és az elforgatás szöge $(\Theta)$ meghatározására szolgál. SST: teljes eltérésnégyzet-összeg, SSR: a regresszió által megmagyarázott eltérésnégyzet-összeg, SSE: a regresszió által nem magyarázott (reziduális) eltérésnégyzet-összeg. A kétdimenziós regresszió hátteréről lásd bővebben Dusek (2011, 14-15. old.).

\section{Súlypontok mozgásának vizsgálata (standard távolság)}

A súlypontok mozgásának jellemzésére a súlypontok standard távolságát számítottuk ki, mely lényegében a pontok térbeli szórásának egy mutatószáma. A térben szórt pontminták nagyobb standard távolságokkal, míg a klaszterezettebb pontok kisebb standard távolságokkal rendelkeznek. A standard távolság kiszámításának első lépése a súlypontok átlagközpontjának kiszámítása volt, mely lényegében a súlypont-koordináták számtani átlaga. Ehhez viszonyítjuk a koordináták átlagos

Területi Statisztika, 2019, 59(4): 353-380; DOI: 10.15196/TS590401 
mozgását mind a teljes időszakban, mind pedig annak két szakaszában. A standard távolság alapvetôen a súlypontok térbeli szórásának mutatószáma, lényegében egy az átlagközpont körül meghúzott kör sugara. A standard távolság képlete a következő:

$$
S_{D}=\sqrt{\sum_{i=1}^{n} \frac{\left(X_{i}-\bar{X}\right)^{2}}{n}+\sum_{i=1}^{n} \frac{\left(Y_{i}-\bar{Y}\right)^{2}}{n}}
$$

ahol $\mathrm{S}_{\mathrm{D}}$ a standard távolság, jelen esetben földrajzi fok, $\mathrm{X}_{\mathrm{i}}$ és $\mathrm{Y}_{\mathrm{i}}$ a súlypontok koordinátái, $\bar{X}$ és $\bar{Y}$ a súlypontok átlagközpontjának koordinátái, $\mathrm{n}$ a vizsgált évek száma.

\section{Struktúraváltozás tesztelése - Chow-teszł}

A gazdasági és az energetikai erőtereket ábrázoló térképeken jól látható (Eredmények fejezet), hogy az ezredfordulót követően az elmozdulás iránya jelentősen megváltozott (mind globálisan, mind az egyes kontinenseken), mely strukturális változásra (más néven strukturális törésre) utal. Ennek vizsgálatát a minta szétbontásán alapuló próbával, nevezetesen a Chow-teszt alkalmazásával végezzük el. A megfelelő tesztstatisztika Ramanathan $(2003,334$. old.) alapján:

$$
F_{c}=\frac{\left(E S S_{R}-E S S_{1}-E S S_{2}\right) / k}{\left(E S S_{1}+E S S_{2}\right) /(n-2 k)}
$$

A Chow-teszt esetében a nullhipotézisünk a struktúra változatlansága, $\mathrm{H}_{1}$-hipotézisünk a strukturális törés jelenléte.

\section{Eredmények}

A 2. ábrán megneveztük azt a 10 országot, melyek a legnagyobb mértékben részesülnek a világ végső energiafelhasználásából. Közöttük 4 fejlett országot találunk (az energiafelhasználás sorrendjében: Egyesült Államok, Japán, Németország és Kanada), melyek az ábra bal alsó negyedéhez tartoznak, vagyis mind az energiafelhasználás, mind a GDP éves átlagos változása elmarad a világátlagtól. Ez nyilván az erős szolgáltató szektorral (lévén a tercier szektor kevésbé energiaintenzív), az energiahatékonysági intézkedésekkel, illetve a népesség számának stagnálásával (Japán, Németország), illetve kismértékú, kiegyensúlyozott növekedésével (Kanada, Egyesült Államok) magyarázható. Ezekben az országokban már megvalósult a környezeti terhelés és a gazdasági növekedés relatív vagy (bizonyos időszakok esetében) abszolút szétválása (lásd részletesebben Szlávik-Sebestyén Szép 2017).

Az átmeneti gazdaságok közül egyedül Oroszország került be ebbe a TOP10-es listába, a jobb alsó negyedben helyezkedve el: míg energiafelhasználásának éves átlagos változása elmarad a világátlagtól, addig gazdasági növekedéséé meghaladja azt. Oroszországban még mindig érezteti a hatását a nehézipar jelentős részének leépülése, a dezindusztrializáció folyamata, a gazdaság átstrukturálódása. A Világbank (2018a) adatai, illetve Weiner (2016) szerint az orosz gazdaság 2006-ban érte el először az 1991-es szintet (ekkor ismerték el hivatalosan a Szovjetunió felbomlását).

Területi Statisztika, 2019, 59(4): 353-380; DOI: 10.15196/TS590401 
Az egyes országok pozíciójának változása a végső energiafelhasználás, illetve a folyó áron mért GDP éves átlagos változása alapján, 1990-2015

Changes in position of individual countries based on final energy consumption and annual average change in GDP at current prices, 1990-2015

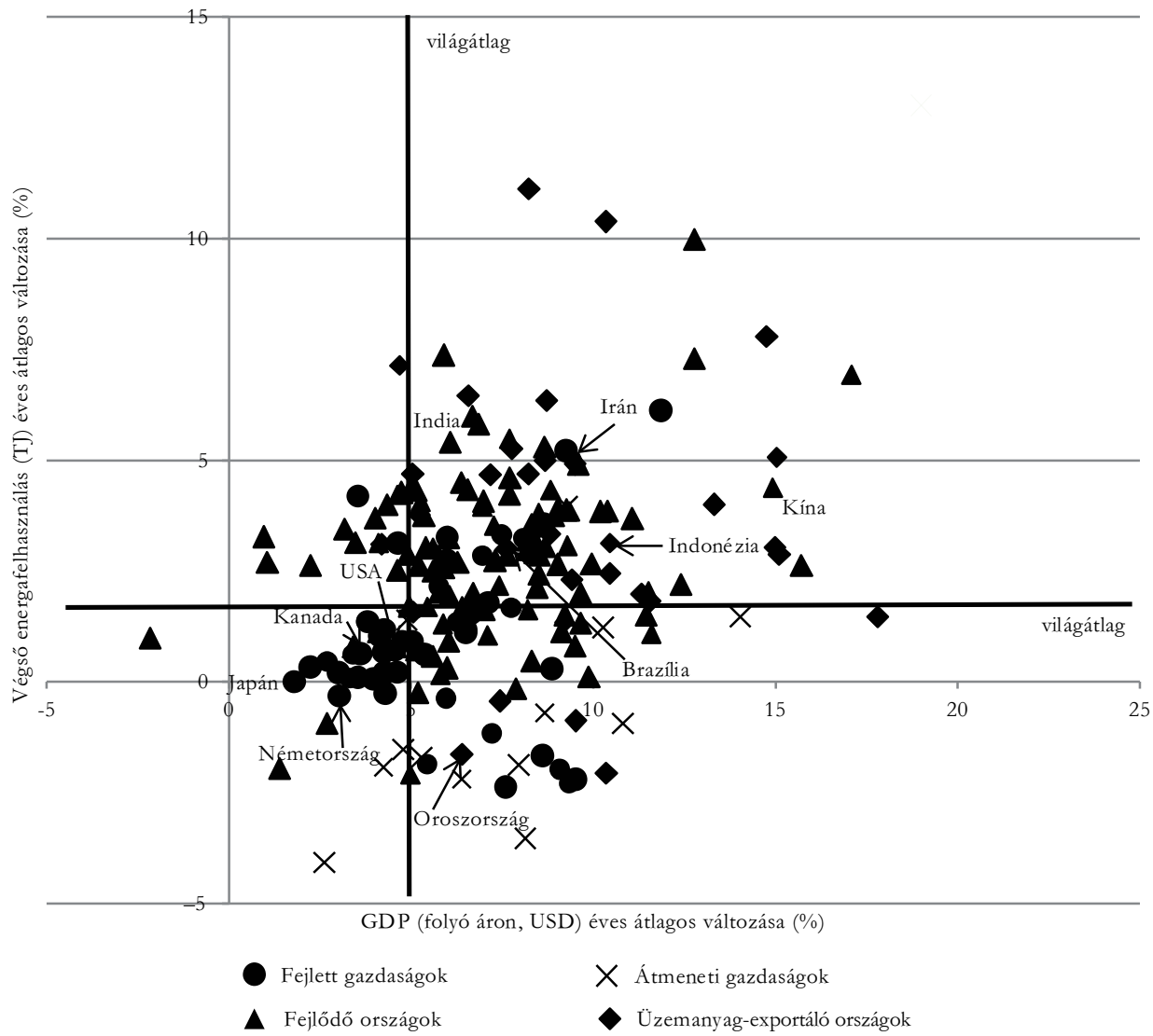

Megjegyzés: fejlett gazdaságok az IMF (2017) szerinti advanced economies, egyéb OECD-országok, egyéb EU- tagállamok; átmeneti gazdaságok az IMF (2017) szerinti economies in transition: Dél-Kelet-Európa átmeneti gazdaságai és a FÁK-országok, valamint Grúzia; üzemanyag-exportáló országok az IMF (2017) szerinti fuel-exporting countries.

Forrás: saját szerkesztés a Világbank (2018a, b) adatbázisai alapján.

A 2. ábra jobb felső sarkában (ahol mindkét mutató éves átlagos változása meghaladja a világátlagot) találjuk Kínát, Indiát, Braziliát, Indonéziát és Iránt. Utóbbi kettő üzemanyag-exportáló ország (bár itt jegyezzük meg, hogy Indonéziában mindössze néhány százalékponttal haladja meg az üzemanyagexport az -importot), Irán a gazdasági szankciók részleges eltörlésével (2015. évi atommegállapodással) összefüggésben 2015-ben már a 10. legnagyobb nettó olajexportőr. Ugyanakkor némi kettősség jellemzi az országot. A gazdaság energiahatékonysága (vagyis az egységnyi

Területi Statisztika, 2019, 59(4): 353-380; DOI: 10.15196/TS590401 
energia felhasználásával elóállítható GDP) a Világbank (2018b) adatai szerint messze elmarad a világátlagtól. 2014-ben ez a mutató 5,6 USD volt (vásárlóerô-paritáson [purchasing power parity - PPP], 2011-es árakon számolva), míg a globális átlag 7,9 USD. Ugyanakkor az egy főre jutó energiafelhasználás értéke igen magas: 3023,5 kilogramm olajegyenérték (a világátlag 1919,4 koe), ami megfelel például az euróövezet átlagának. Az okok egyrészt az energiaintenzív iparágak (olajkitermelés és -finomítás) jelenlétében, a kevésbé fejlett, inkább a közúti közlekedést előtérbe helyező közlekedési szektor magas részesedésében, illetve a nagymértékú támogatásokat élvező, hatósági energiaárakban keresendők (bár ez utóbbiak csökkentése, a támogatási rendszer átláthatóbbá tétele már elkezdődött - lásd részletesen Moshiri 2015). Nyilvánvalóan Kína, India és Brazília az elmúlt években végbemenő expanzív gazdaságpolitika, növekvő népesség, valamint az iparfejlesztési folyamat következtében lettek a világ legnagyobb energiafogyasztói.

\section{A gravitációs erőterek mozgása}

A továbbiakban a gazdasági és az energetikai gravitációs erőterek mozgását mutatjuk be (3. és 4. ábra). Afrikában a gazdasági és az energetikai gravitációs erőtér szinte egybeesik a kontinens mértani közepével, ugyanis a Közép-afrikai Köztársaságban, illetve a Kongói Demokratikus Köztársaságban helyezkedik el. Az elmozdulások kismértékűek, bár sok esetben hektikusan módosulnak: míg az energetikai erőtér egyértelmủen észak felé mozdul el (elsősorban az észak-afrikai országokban végbemenő népesség- és gazdasági növekedés eredményeként), addig a gazdasági gravitációs erőtér 2001/2002-ig követi ezt az irányt, majd 2010-ig délnek tart, azután újra északnak fordul.

Talán az amerikai kontinens mutatja leginkább a kevés cikket exportáló, exportorientált fejlődő országok sebezhetőségét a világgazdasági válságokkal, illetve a különböző nyersanyagok világpiaci árának ingadozásával kapcsolatban. A dél-amerikai kontinens - az 1980-as évek adósságválságát követô reformfolyamatok eredményeként - az 1990-es évek első felében intenzív gazdasági növekedést mutatott. Az 1990 és 1995 közötti időszakban a gazdasági erőtér délkeleti irányba mozdult el. Ugyanakkor a Délkelet-Ázsiából kiinduló 1997-1998-as válság erősen visszavetette az éppen csak megindult fejlődést, az erőtér újra északnyugatnak fordult. A 2000-es évek elején a dotcom lufi ${ }^{1}$ kipukkadása kicsit visszafogja az észak-amerikai kontinens növekedési ütemét, ugyanakkor Argentína és Brazília intenzív fejlődést mutatott, aminek eredményeként újra délkeleti irányba tartott a gravitációs erôtér. A 20082009-es válság sokáig úgy tűnt, hogy elkerüli Dél-Amerikát, de végül a nyersanyagárak esése, majd stagnálása, a visszafogott beruházói kedv, illetve a világgazdaság (és

${ }^{1}$ A dotkom lufi a kizárólag az interneten zajló üzletágban ismert fogalom, az ilyen üzleti lehetőségek „kipukkanására” utal. Az angol dotcom kifejezés az internetes üzleti oldalak.com végződésére utal.

Területi Statisztika, 2019, 59(4): 353-380; DOI: 10.15196/TS590401 
elsősorban Kína) gazdasági növekedési ütemének lassulása elérte a kontinenst, ismét északnyugati irányba fordítva az erôteret.

Ezzel szemben az energetikai erôtér stabilan délkeleti irányba tartott a vizsgált időszakban az amerikai kontinensen, és ezt a különböző gazdasági válságok sem tudták érdemben befolyásolni. Ez egyrészt összefüggésben van Észak-Amerikában az energiahatékonyság javulásával, valamint a szolgáltató szektor fejlődésével, vagyis a gazdasági szerkezet változásával. Tehát a kontinens északi része egyre hatékonyabbá vált, (1990 és 2015 között több mint 10\%-kal) csökkent az egy főre jutó energiafelhasználás, és nőtt az egységnyi energiafelhasználásra jutó GDP (ez a mutató 55\%-kal nőtt a vizsgált időszakban az Egyesült Államokban - a Világbank (2018b) adatai szerint). Ezzel szemben Dél-Amerikában a fajlagos energiafelhasználás a javuló életszínvonallal, illetve a gazdasági fejlődéssel párhuzamosan folyamatosan nőtt, míg a gazdaság energiaintenzitása nem változott.

Európa esetében a kontinenshez tartozónak vettük Oroszországot. Döntésünket elsősorban az indokolja, hogy mind az ország gazdasági teljesítményének, mind lakosságának jelentősebb része földrajzilag Európához kötődik. Jelen esetben figyelmen kívül hagyjuk azokat a geopolitikai elméleteket, melyek Európát mindössze Ázsia nyugati félszigetének tekintik, és az eurázsiai erőteret tartják meghatározónak (lásd bővebben Brzezinski 2017). Ez alapján Európa mértani közepe Oroszország keleti felén helyezkedik el. Érdekes módon ez az a kontinens, ahol szinte teljesen egy irányba mozog a gazdasági és az energetikai erőtér, bár körülbelül 5 éves késleltetéssel. Az elmozdulás iránya nyugat-délnyugat, de míg a gazdasági növekedés esetében 2000-ben a gravitációs erőtér keleti irányba fordult, addig a végső energiafelhasználás esetében ez 5 évvel később, 2005-ben következett be. Ez összefügghet azzal, hogy a rendszerváltást követően a kelet-közép-európai országokban az ipari termelés visszaesése gyorsan (néhány év leforgása alatt) bekövetkezett, ugyanakkor a liberális és privatizációs gazdaságpolitika eredményeként nagy mennyiségú külföldi múködő tőke áramlott be, gyorsan növekedési pályára állitva ezen országok gazdaságát. Fejlődésnek indult a bankrendszer, nőtt a szolgáltató szektor nemzetgazdaságon belüli aránya. Vagyis a kelet-közép-európai országok fokozatosan visszanyerték gazdasági pozíciójukat a kontinensen belül. 2005-öt követően az általános világgazdasági konjunktúra eredményeként megállt az energiafelhasználás csökkenése, az energiaintenzitás pedig stagnált. A 2008-2009-es válságot követően előtérbe kerül az újraiparosítás, felértékelődött az ipari szektor, melynek eredményeként az energiafelhasználás súlypontja ismét keletebbre tolódott.

Területi Statisztika, 2019, 59(4): 353-380; DOI: 10.15196/TS590401 


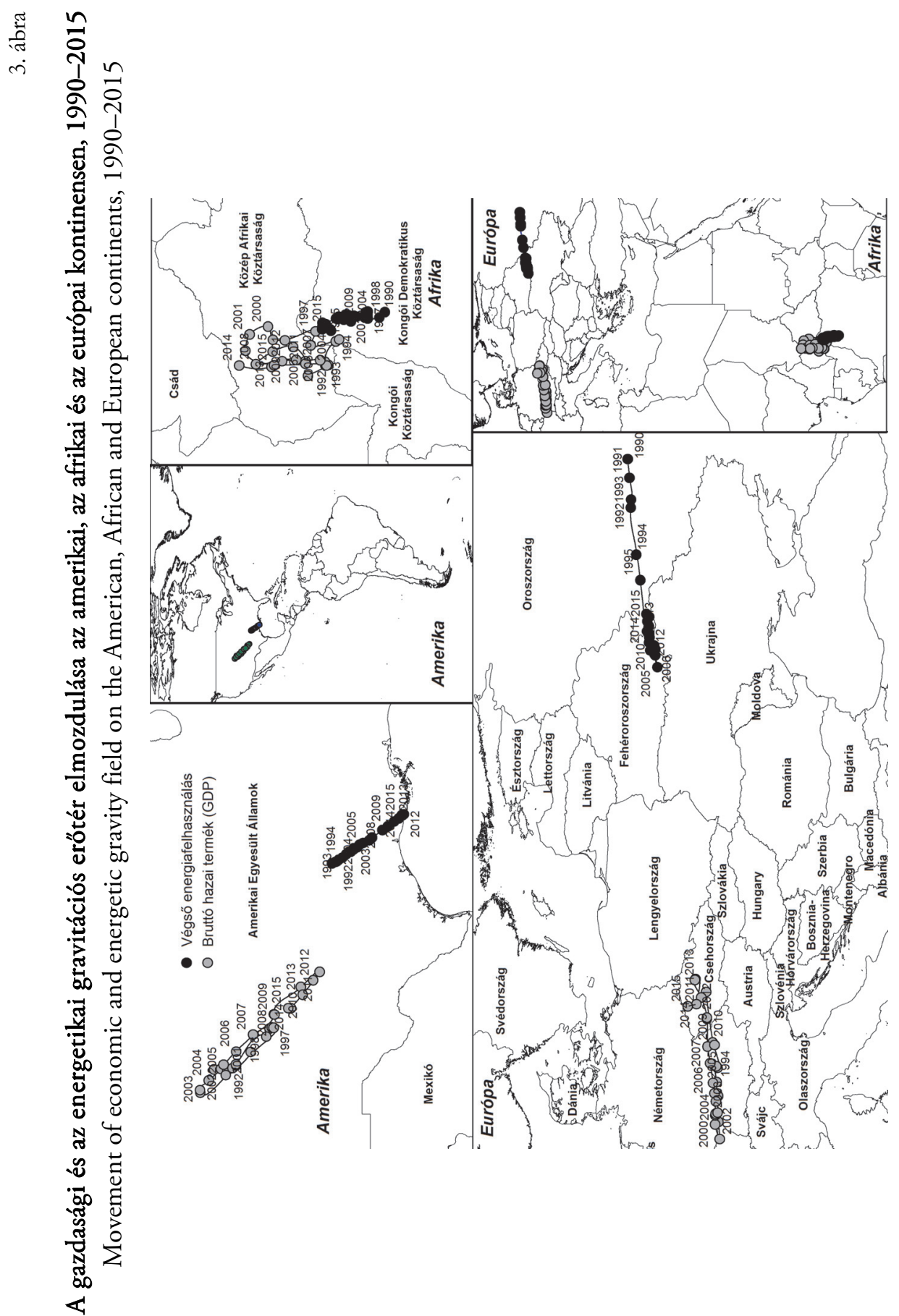

Területi Statisztika, 2019, 59(4): 353-380; DOI: 10.15196/TS590401 


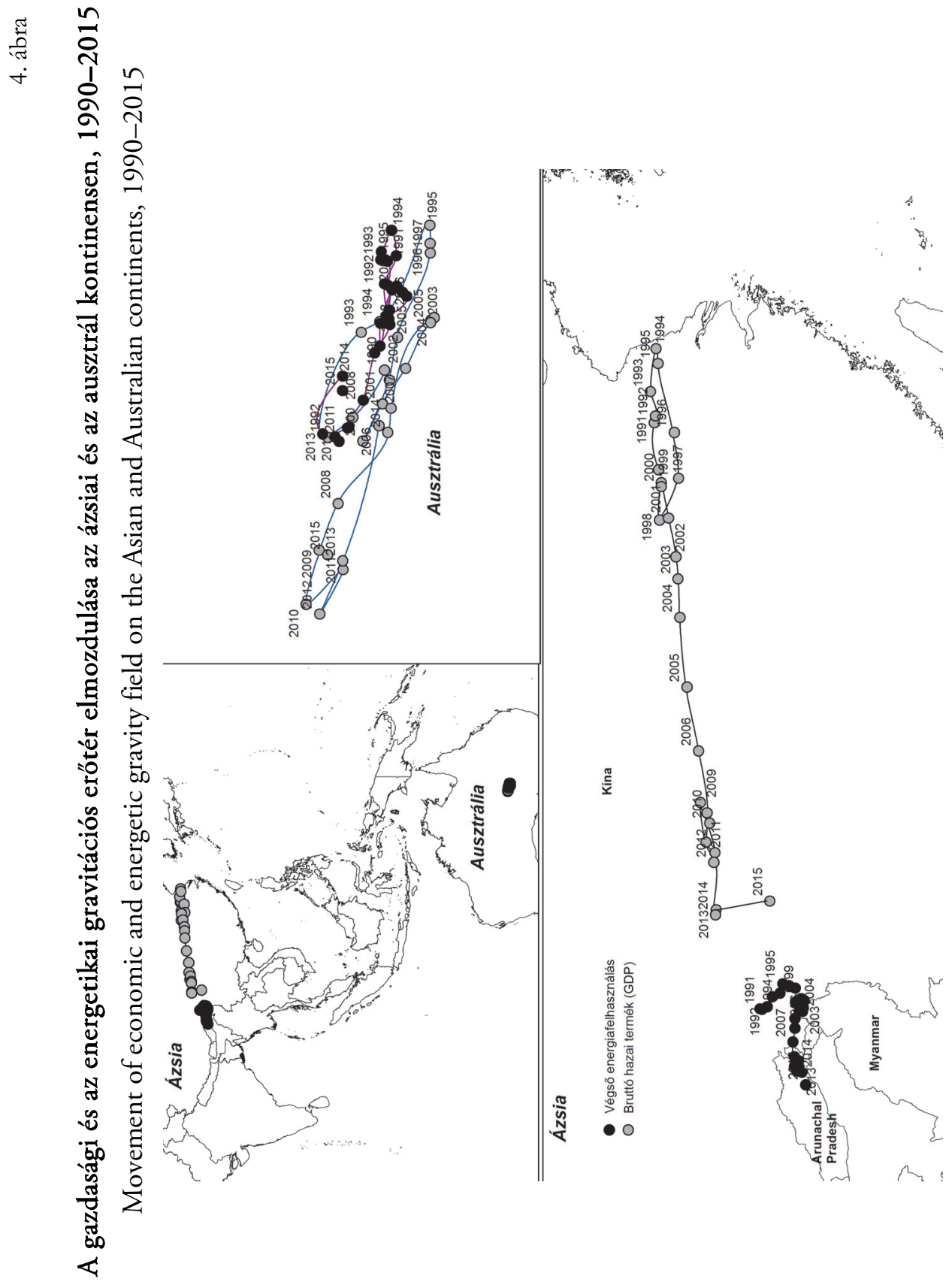

Területi Statisztika, 2019, 59(4): 353-380; DOI: 10.15196/TS590401 
Azssia esetében a gazdasági erőtér súlypontja 1990 és 2015 között végig Kínában helyezkedik el, az energetikai erőtér ezzel szemben 2007 után Kínából Banglades keleti részébe mozdult el. 1995-ig a kontinens gazdasági súlypontja még keleti irányba haladt a délkelet-ázsiai kistigrisek növekvő gazdasági teljesítményének következtében, majd Kína a sikeres „reform és nyitás” politikájával egyre meghatározóbb szereplővé vált. Ennek eredményeként az ezredfordulót követően nyugati irányba mozdult el a gazdasági erőtér súlypontja. 2014 és 2015 között egy viszonylag nagy elmozdulás figyelhetô meg dél-délkeleti irányba, ami elsősorban Kína lassuló gazdasági növekedésével magyarázható. Az energetikai erőtér mozgása kevésbé dinamikus az ázsiai kontinensen. 2000-ig délkeleti irányba tartott, majd ezt követően egyértelmúen nyugati irányba, ami kapcsolatban állhat - többek között - India növekvő energiaéhségével. Az IEA (2017) adatai szerint 2016-ban már India volt a világ 2. legnagyobb szénimportőre (Kína után), illetve a 3. legnagyobb olajimportôre. Ugyanakkor valószínúleg azért kisebb az elmozdulás ebben az esetben - összehasonlítva a GDP-vel - mert a gazdasági szerkezetváltozás megkésett a kontinensen, az ipari szektor nemzetgazdasági részesedése még mindig magas, jelentős strukturális átalakulás nem érzékelhető.

Ausztrália és Óceánia tekintetében természetesen a gazdasági és az energetikai súlypont is - a legnagyobb jelentőségú - Ausztrália területén mozog. Az ausztrál kontinensen belül az elmozdulás nem tekinthető jelentôsnek, a vizsgált országcsoporton belüli ausztrál dominanciával összefüggésben.

Globálisan (5. ábra) a vizsgált időszak 3 jól elkülöníthető szakaszra osztható. 1990 és 1995 között a gazdasági és az energetikai erőtér ellentétes irányba haladt. A gazdasági erőtér délkeleti irányba mozdult el, jelezve Kína felemelkedését és az egyre jelentősebbé váló reformok sikerét (lásd bővebben Ifj. Simon 2001). Ezzel szemben az energetikai erőtér mozgása dél-délnyugati irányultságot vett fel, ami elsősorban Oroszország, illetve a szovjet érdekszférába tartozó országok magasan energiaintenzív nehéziparának leépülésével, továbbá az ipari termelés drasztikus csökkenésével, a gazdasági szerkezet átrendeződésével magyarázható. Ezt követően egészen az ezredfordulóig nem azonosítható jelentős elmozdulás, ez sokkal inkább a kiútkeresés, az egy helyben „toporgás” időszaka. Egyik évben még keleti irányba mozdult el a gravitációs erőtér, a következő évben pedig ellentétes irányba. Ez részben azzal magyarázható, hogy a Szovjetunió felbomlásával (1991) a világ egypólusúvá vált, azonban ez kérészéletúnek bizonyult, új kihívók jelentek meg a világgazdaság színpadán, az erőtereket is hol az egyik, hol a másik irányba húzva. 2001-2002 körül ez a bizonytalanság megszűnt, egyértelműen nyugat-délnyugati irányba tolódott el mind a gazdasági, mind az energetikai gravitációs erőtér. A két erőtér ebben az időszakban együtt mozgott, az elmozdulás nagysága és irányba szinte tökéletesen megegyezett. 


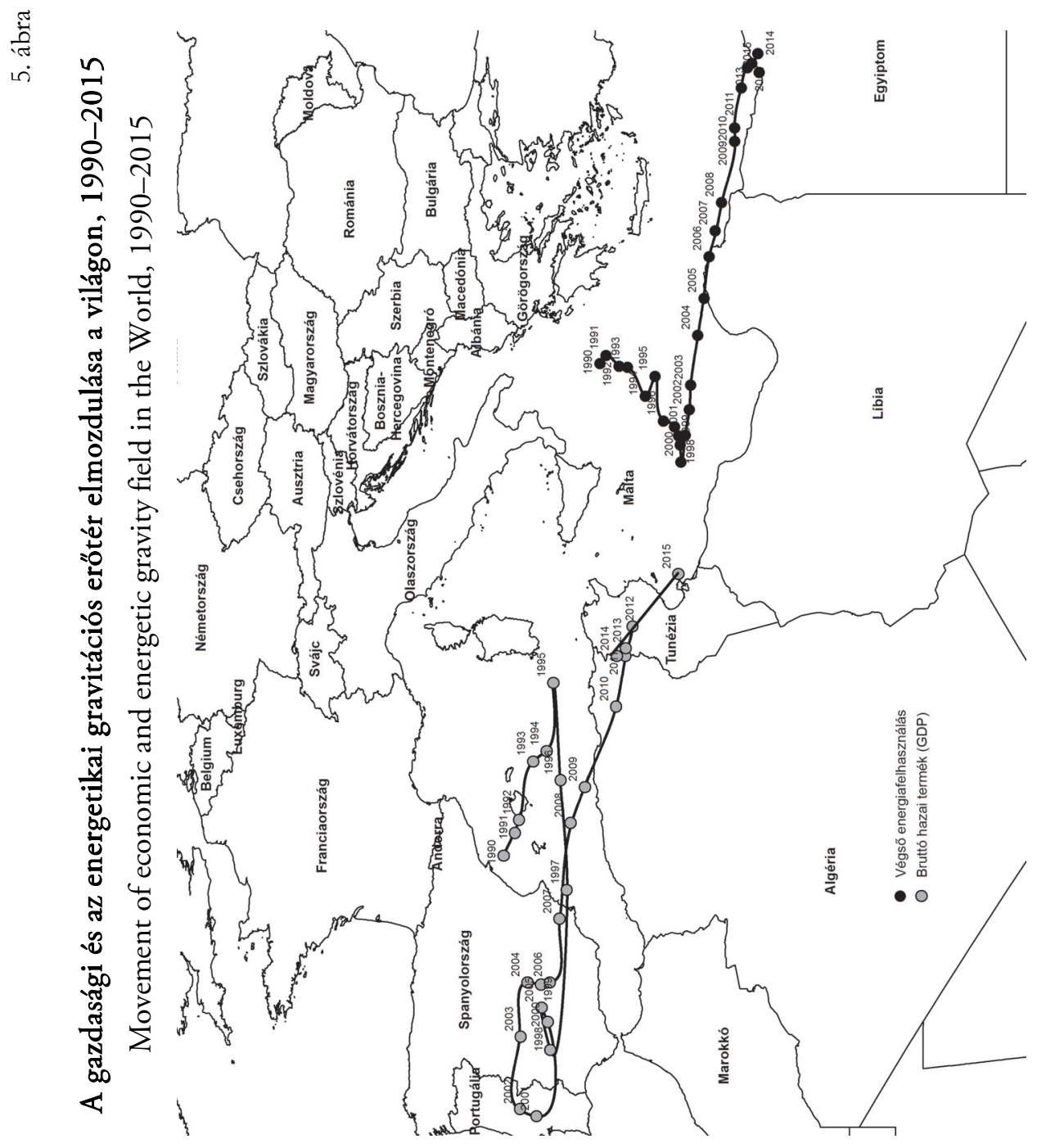

Területi Statisztika, 2019, 59(4): 353-380; DOI: 10.15196/TS590401 
A gazdasági és az energetikai gravitációs erőtér a Földközi-tenger medencéjében található (bár részben elmozdult Spanyolország - az Ibériai-félsziget - felől Tunézia, illetve a Földközi-tenger keleti pereme felé), egyértelmúen jelezve Észak dominanciáját. Ugyanakkor ez a délkeleti irányba történő fokozatos haladás rávilágít az északi félteke szerepének csökkenésére (pozícióvesztésére) és a fejlődő (feltörekvő) országok (Dél) egyre fontosabbá válására.

\section{A súlypontok mozgása}

A súlypontok mozgásának jellemzésére számszerűsítjük a súlypontok standard távolságát, az eredményeinket a 3. táblázat tartalmazza. Megállapítható, hogy a GDPsúlypontok mozgása jóval nagyobb minden kontinensen és minden időszakban, mint a végső energiafelhasználás súlypontjaié. Általánosságban megállapítható, hogy az 1990 és 2000 közötti időszakban kisebb volt a súlypontok mozgása, mint 2001 és 2015 között.

A gazdasági és az energetikai súlypontok súlyozott átlagtávolsága (fok)

Weighted average distance of economic and energetic weighted mean centres (degrees)

\begin{tabular}{|c|c|c|c|}
\hline Kontinens & Időszak & GDP & $\begin{array}{c}\text { Végső } \\
\text { energiafelhasználás }\end{array}$ \\
\hline Világ & $\begin{array}{l}1990-2015 \\
1990-2000 \\
2001-2015\end{array}$ & $\begin{array}{l}5,90 \\
4,22 \\
6,08\end{array}$ & $\begin{array}{l}5,28 \\
1,68 \\
3,91\end{array}$ \\
\hline Afrika & $\begin{array}{l}1990-2015 \\
1990-2000 \\
2001-2015\end{array}$ & $\begin{array}{l}1,30 \\
1,16 \\
0,97\end{array}$ & $\begin{array}{l}0,77 \\
0,36 \\
0,43\end{array}$ \\
\hline Amerika & $\begin{array}{l}1990-2015 \\
1990-2000 \\
2001-2015\end{array}$ & $\begin{array}{l}2,65 \\
1,49 \\
2,65\end{array}$ & $\begin{array}{l}1,54 \\
0,53 \\
1,13\end{array}$ \\
\hline Ázsia & $\begin{array}{l}1990-2015 \\
1990-2000 \\
2001-2015 \\
\end{array}$ & $\begin{array}{l}6,60 \\
1,80 \\
3,38\end{array}$ & $\begin{array}{l}1,15 \\
0,58 \\
0,80\end{array}$ \\
\hline Ausztrália & $\begin{array}{l}1990-2015 \\
1990-2000 \\
2001-2015\end{array}$ & $\begin{array}{l}0,46 \\
0,31 \\
0,42\end{array}$ & $\begin{array}{l}0,27 \\
0,13 \\
0,22\end{array}$ \\
\hline Európa & $\begin{array}{l}1990-2015 \\
1990-2000 \\
2001-2015\end{array}$ & $\begin{array}{l}2,36 \\
1,91 \\
1,96\end{array}$ & $\begin{array}{l}2,86 \\
0,43 \\
0,83\end{array}$ \\
\hline
\end{tabular}

\section{Kétdimenziós regresszió alkalmazásának eredményei}

A kétdimenziós regresszió számításának egyik célja annak feltárása, hogy a GDP esetében kiszámított súlypontokból milyen geometriai elmozdulás után lehet az energetikai súlypontokhoz jutni. A 4. táblázatban bemutatott eredményeink alapján a GDP, 
illetve a végső energiafelhasználás alapján számított gravitációs súlypontok közötti korrelációs kapcsolat erős Ázsiában (0,746), közepes erősségű globálisan $(0,532)$, Amerikában $(0,615)$ és Ausztráliában $(0,621)$, Afrikában $(0,378)$ és Európában $(0,182)$ viszont jóval gyengébb. A $\Phi$ értéke minden esetben kisebb 1-nél, ami alapvetôen kicsinyítést jelentene, bár ebben az esetben nem térbeli alakzatokat, hanem csupán pontokat hasonlítunk össze. A módszer szerint, ha $\Theta=0$, akkor az XY koordinátarendszert nem kell elforgatni, ha negatív, akkor az az óramutató járásával megegyező elforgatást jelent. Ez utóbbit láthatjuk Amerika és Ausztrália vonatkozásában, míg a többi kontinensnél (Afrika, Ázsia, Európa, világ) a GDP és a végső energiafelhasználás közötti kapcsolat inkább az óramutató járásával ellentétes elforgatást jelez. Az SSR, vagyis a regresszió által magyarázott eltérésnégyzet-összeg nagysága Ázsiában a legmagasabb, meghaladja a 80\%-ot, illetve közepes magyarázó erejủ az amerikai és az ausztrál kontinens esetében (hasonlóan a korrelációszámítás eredményéhez). Ezzel szemben a két gravitációs ponthalmazból számított regresszió által magyarázott eltérésnégyzet-összeg Európában csak mintegy 7\%, vagyis a modell magyarázó ereje nagyon kicsi, itt találjuk a legnagyobb hibatagot (93,45\%). Európához hasonlóan Afrikában is kicsi az SSR értéke (26,52\%), globálisan pedig közepes.

4. táblázat

Kétdimenziós regresszió a GDP, illetve a végső energiafelhasználás esetében számított gravitációs erőterek között

Bi-dimensional regression between GDP and gravity fields calculated for final energy use

\begin{tabular}{|c|c|c|c|c|c|c|c|c|c|c|c|}
\hline \multirow{2}{*}{ Kontinens } & \multirow{2}{*}{ Időszak } & \multirow[b]{2}{*}{$\mathrm{r}$} & \multirow[b]{2}{*}{$\alpha_{1}$} & \multirow{2}{*}{$\alpha_{2}$} & \multirow{2}{*}{$\beta_{1}$} & \multirow{2}{*}{$\beta_{2}$} & \multirow{2}{*}{$\Phi$} & \multirow{2}{*}{$\Theta$} & SST & SSR & SSE \\
\hline & & & & & & & & & \multicolumn{3}{|c|}{$\%$} \\
\hline \multirow{3}{*}{ Világ } & $1990-2015$ & 0,532 & 24,78 & 9,40 & 0,63 & 0,11 & 0,64 & 0,17 & 100 & 48,67 & 51,33 \\
\hline & $1990-2000$ & 0,519 & 20,87 & 24,93 & 0,26 & 0,09 & 0,27 & 0,36 & 100 & 46,61 & 53,39 \\
\hline & $2001-2015$ & 0,894 & 24,43 & 5,06 & 0,73 & 0,03 & 0,73 & 0,05 & 100 & 95,94 & 4,06 \\
\hline \multirow{3}{*}{ Afrika } & 1990-2015 & 0,378 & 14,36 & 1,36 & 0,29 & 0,00 & 0,29 & 0,01 & 100 & 26,52 & 73,48 \\
\hline & $1990-2000$ & 0,428 & 17,70 & $-0,42$ & 0,14 & 0,11 & 0,18 & 0,75 & 100 & 33,32 & 66,68 \\
\hline & $2001-2015$ & 0,144 & 18,20 & 3,05 & 0,08 & 0,00 & 0,08 & $-0,01$ & 100 & 4,09 & 95,91 \\
\hline \multirow{3}{*}{ Amerika } & 1990-2015 & 0,615 & $-51,93$ & 6,01 & 0,43 & $-0,09$ & 0,44 & $-0,21$ & 100 & 61,41 & 38,59 \\
\hline & $1990-2000$ & 0,522 & $-68,59$ & 22,80 & 0,25 & $-0,01$ & 0,25 & $-0,02$ & 100 & 47,00 & 53,00 \\
\hline & $2001-2015$ & 0,852 & $-56,14$ & 9,87 & 0,38 & $-0,07$ & 0,38 & $-0,18$ & 100 & 92,47 & 7,53 \\
\hline \multirow{3}{*}{ Ázsia } & 1990-2015 & 0,746 & 81,07 & 21,94 & 0,15 & 0,02 & 0,15 & 0,11 & 100 & 80,28 & 19,72 \\
\hline & $1990-2000$ & 0,366 & 93,71 & 10,03 & 0,08 & 0,14 & 0,15 & 0,11 & 100 & 25,06 & 74,94 \\
\hline & $2001-2015$ & 0,841 & 75,48 & 26,70 & 0,19 & $-0,04$ & 0,19 & $-0,21$ & 100 & 91,47 & 8,53 \\
\hline \multirow{3}{*}{ Ausztrália } & $1990-2015$ & 0,621 & 75,67 & $-8,53$ & 0,47 & $-0,04$ & 0,47 & $-0,09$ & 100 & 62,32 & 37,68 \\
\hline & $1990-2000$ & 0,130 & 143,15 & $-16,98$ & $-0,01$ & $-0,08$ & 0,08 & 0,05 & 100 & 3,36 & 96,64 \\
\hline & $2001-2015$ & 0,782 & 66,24 & $-10,54$ & 0,53 & $-0,02$ & 0,53 & $-0,03$ & 100 & 84,90 & 15,10 \\
\hline \multirow{3}{*}{ Európa } & $1990-2015$ & 0,182 & 31,11 & 36,36 & 0,32 & 0,04 & 0,32 & 0,12 & 100 & 6,55 & 93,45 \\
\hline & $1990-2000$ & 0,741 & 23,12 & $-26,90$ & 1,60 & 0,09 & 1,60 & 0,06 & 100 & 79,66 & 20,34 \\
\hline & $2001-2015$ & 0,531 & 28,62 & 41,69 & 0,21 & 0,00 & 0,21 & $-0,01$ & 100 & 48,44 & 51,56 \\
\hline
\end{tabular}

Területi Statisztika, 2019, 59(4): 353-380; DOI: 10.15196/TS590401 
Az erőterek elmozdulását mutató térképek vizsgálatából arra következtethetünk, hogy a világon egy irányváltás zajlott le az ezredforduló idején, ami struktúraváltásra utal: az addig nyugati irányba haladó gazdasági erôtér, illetve a délnyugati irányba tartó energetikai erőtér keletnek fordult. A továbbiakban az ehhez kapcsolódó hipotézisvizsgálatot a Chow-teszt segítségével végezzük el. A vizsgált időszakot két szakaszra osztottuk. $\mathrm{H}_{1}$-hipotézisünk szerint az ezredforduló idején struktúraváltozás következett be globálisan, mely elsősorban a világgazdaság bővülésével, illetve a nyersanyagárak hirtelen megindult emelkedésével magyarázható. Ez alapján a vizsgált idôszakot két szakaszra bontottuk: 1990-2000, 2001-2015. A teszteléshez „pooled” a legkisebb négyzetek módszerét (Ordinary Least Squares - OLS), azaz OLS-modellt alkalmaztunk, az okság irányát nem vettük adottnak, vagyis mindkét irányra lefuttattuk számításainkat. Az eredményeket az 5. táblázat mutatja be, mely alapján elutasíthatjuk nullhipotézisünket és elfogadhatjuk a struktúraváltozás jelenlétét.

5. táblázat

\section{Chow-teszt eredményei}

Results of Chow-test

\begin{tabular}{l|l|l}
\hline \multicolumn{1}{c|}{ Megnevezés } & \multicolumn{1}{c|}{ I. eset: függő változó: $\log \_G D P$} & II. eset: függő változó: log_TFEC \\
\hline Tesztstatisztika & $\mathrm{F}(2,4977)=27,2525$ & $\mathrm{~F}(2,4977)=14,5053$ \\
p-érték & $\mathrm{P}(\mathrm{F}(2,4977)>27,2525)=0,000^{* * *}$ & $\mathrm{P}(\mathrm{F}(2,4977)>14,5053)=0,000^{* * *}$
\end{tabular}

A Chow-teszt eredményei alapján a kétdimenziós regressziót mindkét szakaszra kiszámítottuk. Ennek eredményei azt bizonyítják (4. táblázat), hogy az ezredforduló markáns törésvonalat mutat a gazdasági és az energetikai erőterek vonatkozásában. Globális szinten, valamint Amerika, Ázsia és Ausztrália vonatkozásában a korrelációs kapcsolat jelentősen erősödik. Afrika és Európa esetében ezzel éppen ellentétes, gyengülő korrelációs kapcsolat figyelhető meg (az SSR értéke Afrikában 4,09 és Európában 48,44\%), ráadásul az erőtereket jellemző pontalakzatok mozgása közötti kapcsolat nemcsak gyengült, hanem egyértelmúen más irányt is vett, s ez okozta a teljes időszakot jellemző gyenge korrelációs kapcsolatot. Ugyanakkor az elforgatás szögének $(\Theta)$ alakulása az egyes kontinenseken, továbbá a vizsgált időszakokban nem mutatott szabályszerűséget, így - egyelőre - a módszert nem tartottuk alkalmasnak az energiafelhasználás és a gazdasági növekedés közötti ok-okozati kapcsolatok vizsgálatára.

\section{Összefoglalás, következtetések}

A BP (2018) adatai szerint 2040-ig körülbelül egyharmadával fog nőni a globális energiafelhasználás, és ennek a növekménynek körülbelül a felét az ipari szektor fogja adni, regionálisan pedig körülbelül kétharmadát a feltörekvő gazdaságok (elsősorban India és Kína). Ennek nyomán - ahogy azt Bradshaw (2010) is megállapítja a globális energiakeresletben nagyon rövid idő alatt jelentős változások következhet-

Területi Statisztika, 2019, 59(4): 353-380; DOI: 10.15196/TS590401 
nek be, melyek nemcsak az energiaforrások nemzetközi kereskedelmére hatnak ki, hanem az ezzel kapcsolatos globális pénzáramokra is.

Tanulmányunkban a gravitációsmodell-számítások családjába tartozó súlypontmódszerrel, illetve kétdimenziós regresszió segítségével vizsgáltuk meg a gazdasági és az energetikai erőterek 1990 és 2015 közötti elmozdulását a világon (lásd Melléklet), illetve az egyes kontinenseken. Eredményeink kiinduló hipotéziseket csak részben támasztották alá.

Következtetéseink:

1. A gazdasági és az energetikai gravitációs erôtér a Földközi-tenger medencéjében található, bár egy fokozatos, keleti irányba történő elmozdulás figyelhető meg. Ez egyelőre még Észak dominanciáját mutatja, mindazonáltal jelzi az északi félteke szerepének csökkenését (pozícióvesztését) és a fejlődő (feltörekvő) országok (Dél) egyre fontosabbá válását.

2. A GDP, illetve a végső energiafelhasználás alapján számított gravitációs súlypontok között erôs korrelációs kapcsolat csak Ázsiában mutatható ki 1990 és 2015 között. Globálisan, Amerikában és Ausztráliában a korreláció erőssége közepes, Afrikában és Európában jóval gyengébb a kapcsolat. Az eredményeket a regreszszió által magyarázott eltérésnégyzet-összeg nagysága is megerősítette.

3. Az ezredforduló sok tekintetben fordulópontként - struktúraváltásként - értelmezhetô. Ezt követően a két vizsgált indikátor együttmozgása szorosabbá válik, mely fokozottan érzékelhető az amerikai, ázsiai és ausztrál kontinensen, illetve globálisan. Afrika és Európa esetében ezzel éppen ellentétes, gyengülő korrelációs kapcsolat figyelhető meg.

4. A gravitációsmodell-számítás és a kétdimenziós regresszióvizsgálat csak korlátozott mértékben alkalmas a vizsgált gazdasági és energetikai változók közötti oksági kapcsolatok identifikálására, ezért a téma további vizsgálata szükséges.

\section{Köszönetnyilvánítás}

A kutatást az EFOP-3.6.2-16-2017-00007 azonosító számú, Az intelligens, fenntartható és inkluziv társadalom fejlesztésének aspektusai: társadalmi, technológiai, innovációs hálózatok a foglalkoztatásban és a digitális gazdaságban című projekt támogatta. A projekt az Európai Unió támogatásával, az Európai Szociális Alap és Magyarország költségvetése társfinanszírozásában valósult meg.

Területi Statisztika, 2019, 59(4): 353-380; DOI: 10.15196/TS590401 

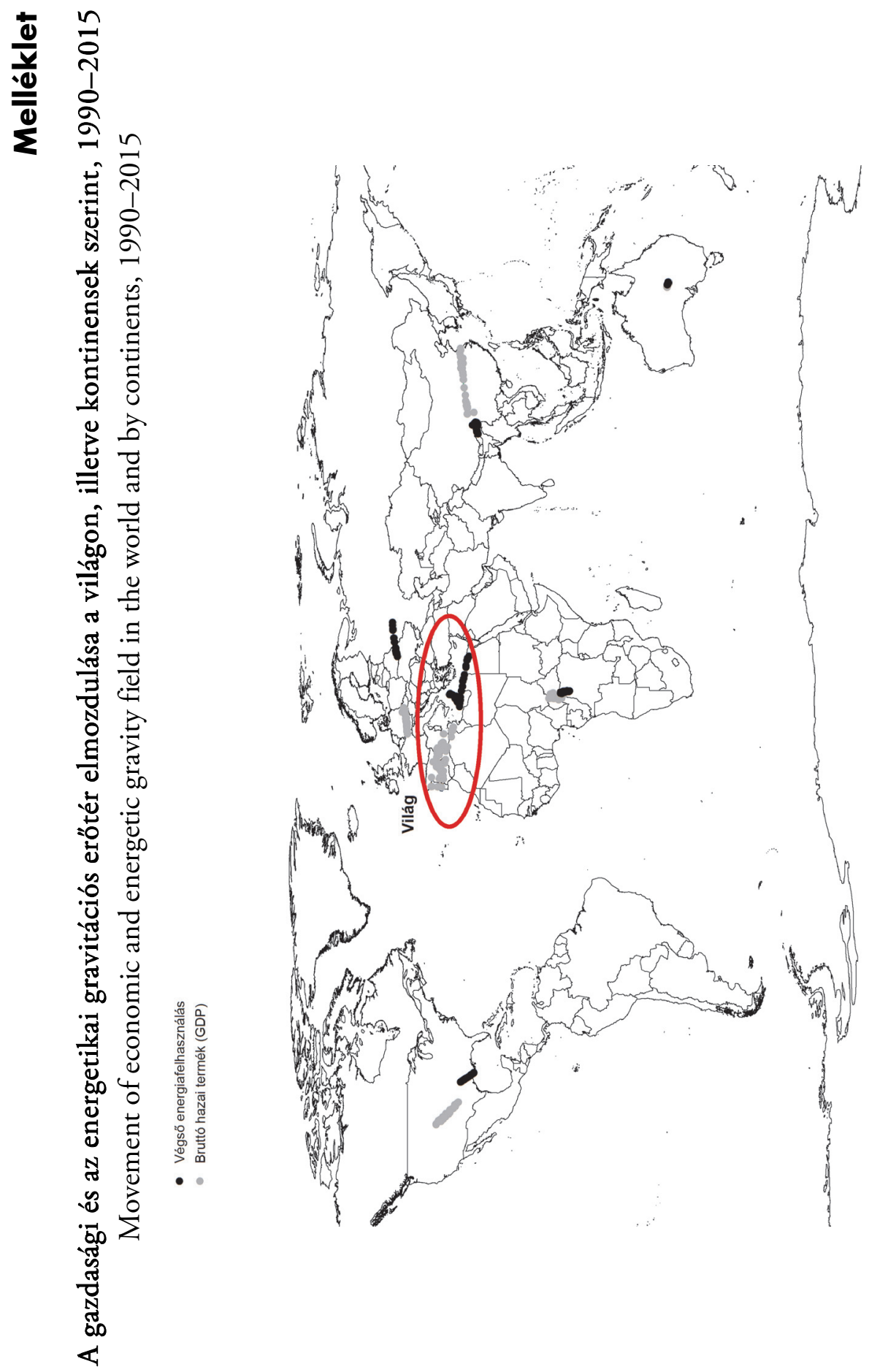

Területi Statisztika, 2019, 59(4): 353-380; DOI: 10.15196/TS590401 


\section{IRODALOM}

Akizu, O.-Urkidi, L.-Bueno, G.-Lago, R.-BArcena, I.-MAntXo, M.-Basurko, I.LopeZ-GuedE, J. M. (2017): Tracing the emerging energy transitions in the Global North and the Global South International Journal of Hydrogen Energy 42 (28): 18045-18063. https://doi.org/10.1016/j.ijhydene.2017.04.297

Arto, I.-CApellán-Pérez, I.-Lago, R.-Bueno, G.-Bermejo, R. (2016): The energy requirement of a developed world Energy for Sustainable Development 33: 1-13. https://doi.org/10.1016/j.esd.2016.04.001

AYRES, R. U.-AYRES, L. W.-WARR, B. (2003): Exergy, power and work in the US economy, 1900-1998 Energy 28 (3): 219-273. https://doi.org/10.1016/S0360-5442(02)00089-0

Ayres, R. U.-WARR, B. (2005): Accounting for growth: the role of physical work Structural Change and Economic Dynamics 16 (2): 181-209. https://doi.org/10.1016/j.strueco.2003.10.003

BERNDT, E. R.-WOOD, D. O. (1975): Technology, prices and the derived demand for energy The Review of Economics and Statistics 57 (3): 259-268. https://doi.org/10.2307/1923910

Bradshaw, M. J. (2010): Global energy dilemmas: a geographical perspective The Geographical Journal 176 (4): 275-290. https://doi.org/10.1111/j.1475-4959.2010.00375.x

BRZEZINSKI, Z. (2017): A nagy sakektábla Antall József Tudásközpont, Budapest.

CALVERT, K. (2016): From „energy geography” to „energy geographies”: perspectives on a fertile academic borderland Progress in Human Geography 40 (1): 105-125. https://doi.org/10.1177/0309132514566343

Cleveland, C. J. (2003): Biophysical constraints to Economic growth In GOBAISI, D. AL Encyclopedia of Life Support Systems UNESCO, Paris.

Csomós, G.-Tóth, G. (2016): Mapping the position of cities in corporate research and development through a gravity model-based bidimensional regression analysis Regional Statistics 6 (1): 217-220. https://doi.org/10.15196/RS06111

Duncan, R. (2006): The Olduvai Theory-Energy, Population and Industrial Civilization The Social Contract 16 (2): article No. 1362.

Durocher S.-LEBLANC A.-SKALA M. (2017): The projection median as a weighted average Journal of Computational Geometry 8 (1): 78-104. http://dx.doi.org/10.20382/jocg.v8i1a5

DusEK, T. (2011): Kétdimenziós regresszió a területi kutatásokban Területi Statisz̨tika 51 (1): $11-22$.

DusEK, T. (2012): Bidimensional Regression in Spatial Analysis Regional Statistics 2 (1): 61-73.

FESHARAKI, F. (1996): Asia as the center of gravity of the world energy system Energy 21 (11): 999-1003.

Friedman, A.-KoHLER, B. (2003): Bidimensional Regression: Assessing the Configural Similarity and Accuracy of Cognitive Maps and Other Two-Dimensional Data Sets Psychological Methods 8 (4): 468-491.

https://doi.org/10.1037/1082-989X.8.4.468

Területi Statisztika, 2019, 59(4): 353-380; DOI: 10.15196/TS590401 
GRETHER, J.-MATHYS, N. A. (2010): Is the world's economic centre of gravity already in Asia? Area 42 (1): 47-50. https://doi.org/10.1111/j.1475-4762.2009.00895.x

GuZIK, R.-KoŁoś, A.- GWosDZ, K. (2017): Interconnections in public transport as a method for delimiting urban functional areas and the settlement hierarchy in Poland Regional Statistics 7 (1): 63-77. https://doi.org/10.15196/RS07104

KINCSES, Á.-TÓTH, G. (2012): Gravitációs modell alkalmazása a térszerkezet vizsgálatára Területi Statisztikea 52 (5): 479-491.

KLEIN, L. R. (2009): Measurement of a shift in the world's center of economic gravity Journal of Policy Modeling 31 (4): 489-492. https://doi.org/10.1016/j.jpolmod.2009.05.005

KovÁcs, F. (2007a): Energiaigények és a világ szénkészletei A Miskolci Egyetem Közleménye A sorozat, Bányászat 71: 63-74.

KovÁCs, F. (2007b): A megújuló energiafajták várható arányai az energiaigények kielégítésében A Miskolci Egyetem Közleménye A sorozat, Bányászat 71: 47-62.

KRAFT, J.-KRAFT, A. (1978): On the relationship between energy and GNP Journal of Energy and Development 3 (2): 401-403.

MoshiRI, S. (2015): The effects of the energy price reform on households consumption in Iran Energy Policy 79: 177-188. https://doi.org/10.1016/j.enpol.2015.01.012

MurPhy, D. J.-HALL, C. A. S. (2011): Adjusting the economy to the new energy realities of the second half of the age of oil Ecological Modelling 223 (1): 67-71. https://doi.org/10.1016/j.ecolmodel.2011.06.022

NAGY, G. (2011): A gravitációs modell felhasználásának lehetőségei a várostérségek lehatárolásában Területi Statiştike 51 (6): 656-673.

QUAH, D. (2011): The global economy's shifting centre of gravity Global Policy 2 (1): 3-9. https://doi.org/10.1111/j.1758-5899.2010.00066.x

Ramanathan, R. (2003): Bevezetés az ökonometriába alkalmazásokeal Panem Kiadó, Budapest.

SCHurR, S. H. (1982): Energy Efficiency and Productive Efficiency: Some Thoughts Based on American Experience Energy Journal 3 (3): 3-14. https://doi.org/10.5547/ISSN0195-6574-EJ-Vol3-No3-1

IFJ. Simon, GY. (2001): Reform és növekedés Kínában Közgazdasági Szemle 48 (7-8): 673-692.

STERN, D. I. (2000): Aggregation and the role of energy in the economy Ecological Economics 32 (2): 301-317. https://doi.org/10.1016/S0921-8009(99)00113-5

Stern, D. I.-Cleveland, C. J. (2004): Energy and Economic Growth Rensselaer Working Paper in Economics No.0410. Rensselaer Polytechnic Institute, Troy, NY.

STERN, D. I. (2011): The role of energy in economic growth Annals of the New York Academy of Sciences 1219: 26-51. doi: 10.1111/j.1749-6632.2010.05921.x.

SZABÓ, Zs. (2010): A válság hatása Kínára, és Peking gazdaságpolitikai válaszai Magyar Tudomány 171 (4): 439-447.

SZLÁVIK, J.-SEBESTYÉN SZÉP, T. (2017): Delinking of energy consumption and economic growth in the visegrad group Geographia Technica 12 (2): 139-149. https://doi.org/10.21163/GT_2017.122.12

TOBLER, W. R. (1961): Map Transformations of Geographic Space PhD dissertation, University of Washington, Seattle.

Tobler, W. R. (1965): Computation of the Correspondence of Geographical Patterns Papers of the Regional Science Association 15 (1): 131-139. https://doi.org/10.1111/j.1435-5597.1965.tb01318.x

Területi Statisztika, 2019, 59(4): 353-380; DOI: 10.15196/TS590401 
Tobler, W. R. (1970): A Computer Model Simulating Urban Growth in the Detroit Region Economic Geography 46 (2): 234-240. https://doi.org/10.2307/143141

ToBler, W. R. (1978): Comparisons of Plane Forms Geographical Analysis 10 (2): 154-162. https://doi.org/10.1111/j.1538-4632.1978.tb00004.x

ToBler, W. R. (1994): Bidimensional Regression Geographical Analysis 26 (3): 187-212. https://doi.org/10.1111/j.1538-4632.1994.tb00320.x

TOBLER, W. R. (2004): On the First Law of Geography: A Reply Annals of the Association of American Geographers 94 (2): 304-310. https://doi.org/10.1111/j.1467-8306.2004.09402009.x

Tóth, G.-NAGY, Z. (2016): The world's economic centre of gravity Regional Statistics 6 (2): 177-180. https://doi.org/10.15196/RS06210

WANG, W.-ZHANG, M.-LI, P. (2014): Exploring temporal and spatial evolution of global energy production and consumption Renewable and Sustainable Energy Review 30: 943-949. https://doi.org/10.1016/j.rser.2013.11.027

ZHANG, Y.-ZHANG, J.-YANG, Z.-LI, J. (2012): Analysis of the distribution and evolution of energy supply and demand centers of gravity in China Energy Policy 49: 695-706. https://doi.org/10.1016/j.enpol.2012.07.012

ZHANG, N.-LIOR, N.-JIN, H. (2011): The energy situation and its sustainable development strategy in China Energy 36 (6): 3639-3649.

https://doi.org/10.1016/j.energy.2011.01.035

\section{INTERNETES HIVATKOZÁSOK}

BP (2018): Energy Outlook 2018

https://www.bp.com/content/dam/bp/en/corporate/pdf/energy-

economics/energy-outlook/bp-energy-outlook-2018.pdf (letöltve: 2018. július)

JENNESS, J. (2004): Weighted Mean of Points v. 1.2c

http://www.jennessent.com/arcview/weighted_mean.html (letöltve: 2018. június)

IEA (2017): Key world energy statistics Paris.

https://www.iea.org/publications/freepublications/publication/KeyWorld2017. pdf (letöltve: 2017. június)

IMF (2017): World Economic and Financial Surveys World Economic Outlook. Database - WEO Groups and Aggregates Information Washington. https://www.imf.org/external/pubs/ft/weo/2017/01/weodata/groups.htm

LAKATOS, I.-LAKATOSNÉ SZABÓ, J. (2008): A nem konvencionális szénhidrogének jelentősége a XXI. században http://www.mernokkapu.hu/fileok/2/KoolajFoldgaz.pdf (letöltve: 2012. július)

MunKÁCsY, B. (2018): Energiaföldrajz és energiatervezés Eötvös Loránd Tudományegyetem, Természettudományi Kar, Földrajztudományi Központ, Környezet- és Tájföldrajzi Tanszék, Budapest.

http://munkacsy.web.elte.hu/energiafoldrajz\%20tankonyv.pdf (letöltve: 2018. július)

Nemes NAgY, J. (1998): A tér a társadalomkutatásban. Bevezetés a regionális tudományba Hilscher Rezső Szociálpolitikai Egyesület, Budapest.

http://geogr.elte.hu/REF/REF_Kiadvanyok/Ter_a_tarskutban/A_Ter_a_tarsa dalomkutatasban_NNJ.htm (letöltve: 2018. július)

Területi Statisztika, 2019, 59(4): 353-380; DOI: 10.15196/TS590401 
STERN, D. I. (2009): Energy quality

http://mpra.ub.uni-muenchen.de/16857/1/MPRA_paper_16857.pdf (letöltve: 2012. június)

UN (2017): World Economic situation and prospects New York.

https://www.un.org/development/desa/dpad/wp-content/uploads/sites/45/ publication/2017wesp_full_en.pdf (letöltve: 2017. június)

VILÁGBANK (2018a): World Development Indicators adatbázis Washington. http://databank.worldbank.org/data/reports.aspx?source=world-developmentindicators (letöltve: 2018. június)

VILÁGBANK (2018b): Sustainable Energy 4 All adatbázis Washington. https://datacatalog.worldbank.org/dataset/sustainable-energy-all (letöltve: 2018. június)

WEINER, Cs. (2016): Az állam szerepe az orosz gazdaságban MTA Közgazdaság- és Regionális Tudományi Kutatóközpont Világgazdasági Intézet, Budapest. http://real.mtak.hu/44950/1/MT_119_Weiner.pdf (letöltve: 2017. június)

World ENERGY COUNCIL (2017a): World Energy Trilemma Index (2017) Monitoring the sustainability of national energy systems London.

https://trilemma.worldenergy.org/reports/main/2017/2017\%20Energy\%20Trilemma\%20I ndex.pdf (letöltve: 2018. június)

World ENERGy COUNCIL (2017b): World Energy Scenarios 2017 London. https://www.worldenergy.org/wp-content/uploads/2017/05/LACScenarios_Full-Report_FINAL.pdf (letöltve: 2018. június) 